\title{
Banks' climate commitments and credit to brown industries: new evidence for France
}

\author{
Jean-Stéphane Mésonnier ${ }^{1}$
}

November 2019, WP \#743

\begin{abstract}
In this paper, I investigate whether and how banks align green words with deeds in terms of credit allocation across more or less carbon-intensive industries in France. I use a rich dataset of bank credit exposures across some fifty industries and two size classes of borrowing firms for the main banking groups operating in France, which I merge with information on industries' greenhouse gas emission intensities and a score for banks' self-reported climate-related commitments over 2010-2017. I find evidence that higher levels of self-reported climate commitments by banks are associated with less lending to large corporates in the five brownest industries. However, lending to SMEs across more or less carbon-intensive industries remained unrelated to banks' commitments to green their business. Since SMEs are not required to report on their carbon emissions, while large firms are, these findings suggest that devising an appropriate carbon reporting framework for small firms is likely to enhance the decarbonization of bank lending. ${ }^{2}$
\end{abstract}

Keywords: green banks, greenhouse gas emissions, climate change.

JEL classification: G21, Q54.

\footnotetext{
${ }^{1}$ Banque de France (e-mail: jean-stephane.mesonnier@banque-france.fr) and Chair Energy and Prosperity.

${ }^{2}$ I am grateful to Olivier David Zerbib for stimulating discussions at the beginning of this project. I thank Gunther Capelle-Blancard (discussant), Patricia Crifo (discussant), Hubert Kempf, Mathias Lé and Antoine Berthou, as well as participants in a Banque de France seminar and a seminar of the Chair Energy and Prosperity (Risk Foundation, Paris) for their comments. Nicolas Ghio provided very valuable research assistance. The opinions expressed are the author's own and do not necessarily reflect the views of the Banque de France or the Eurosystem.
}

Working Papers reflect the opinions of the authors and do not necessarily express the views of the Banque de France. This document is available on publications.banque-france.fr/en 


\section{NON-TECHNICAL SUMMARY}

Figure 3: Lending shares to top 5 emission-intensive industries: High CDP-rating banks vs others
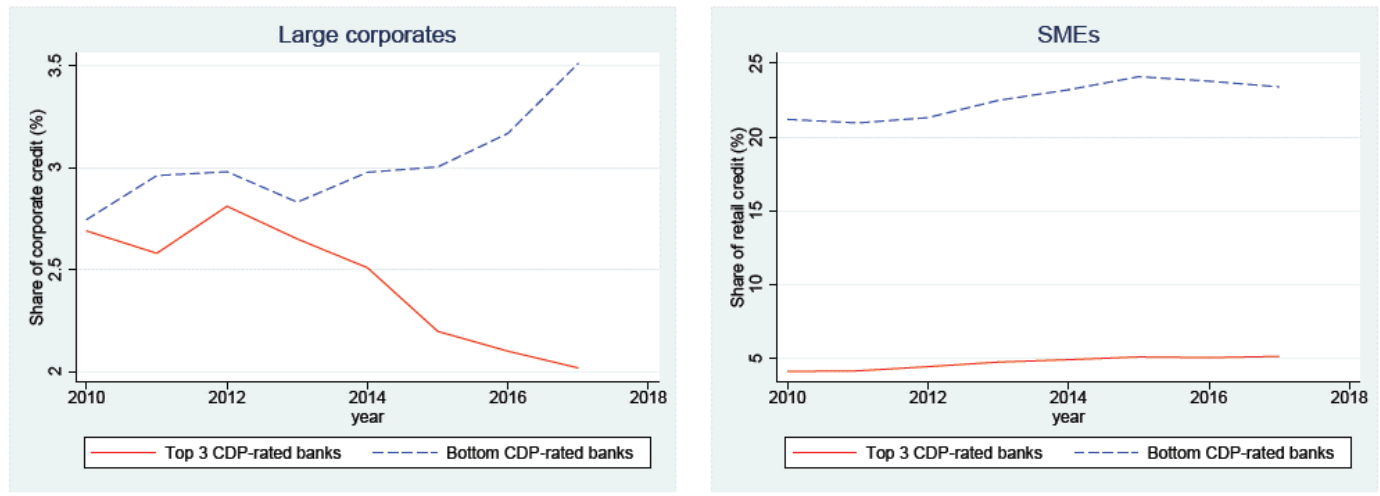

Note. Top CDP-rated banks aggregate the three banking groups with the highest average CDP climate scores over 2010-2016. Bottom CDP-rated banks aggregate the two other banking groups in the main sample and a third major banking group with no CDP rating. Top 5 GHG-intensive sectors are: [C19] Manufacture of coke and refined petroleum products, [H51] Air transport, [C24] Manufacture of basic metals, [A01] Farming, [C23] Manufacture of other non-metallic mineral products.

Effectively addressing the many challenges raised by the ongoing climate change will require to fund huge amounts of public and private investment over the next two decades. According to recent estimates, some $\$ 6,000$ bns of additional green investment would be needed yearly until 2030 at the global level, while only some $\$ 400$ bns yearly are actually invested so far. In France alone, which accounts for some 1.6\% of world carbon emissions, additional funding needs would amount to some EUR 60 bns yearly, but half as much were invested in 2015. Over the last decade, and even more since the Paris Accord of 2015, a number of large banks, including major French groups, have publicly acknowledged they have a role to play in addressing this problem. Consequently, many banking groups have committed to greening their business and signed international statements or even boasted their planned exit out of some carbon-intensive industries. Are these statements by large banks mere greenwashing or is bank credit really being reallocated out of brown firms and brown industries? Considering conflicting recent reports by environmental ONGs, the jury still stands out.

In this paper, I investigate whether banks which claim to be green decrease relatively more their loans to the most carbon-intensive (or "brownest") domestic sectors. For this purpose, I merge information on industries' greenhouse gas (GHG) emission intensities, green ratings of major banking groups that reflect their self-reported climate commitments, and last but not least, the universe of almost all bilateral bank-firm credit exposures in France over 2010-2017. This rich credit dataset allows me to sort bank credit exposures to each industry according to the size of borrowing firms, in order to separately analyze what drives lending to large corporations vs lending to small firms (SMEs). I find robust evidence in support of a more active reallocation of credit out of fossil-based sectors when banks self-report as more committed to climate change mitigation and 
adaptation, as higher climate performance scores are associated with less lending to large firms in the five most emission-intensive sectors. However, there is no sign of any rebalancing of more committed banks' credit across brown vs green industries when it comes to SME lending. This lack of interest in the carbon intensity of retail lending may contribute to explaining while, in additional tests, I cannot find any conclusive evidence of an effect of domestic banks' climate commitments on industry-level GHG emission growth in France over this period of time.

Two important policy implications can be drawn from this study. First, the link I highlight between sector-level carbon intensity, banks' greening and bank lending to large firms suggests that the available industry-level information on GHG emissions is relevant for banks, or at least is a good proxy of the information that is used by banks. This may be a concern as regulators would prefer to incentivize banks to direct credit to the "greenest" corporations within brown industries, i.e. the firms that invest heavily in greening their dirty production process, rather than pushing banks to cut funding to an industry altogether. Second, the results provide support to recent calls for an extension of mandatory carbon disclosure to SMEs (CESE, 2018). However, most SMEs are by themselves not in capacity to comply with new rules imposing a detailed reporting on carbon emissions. To avoid important mis- or under-reporting, the implementation of such an extension of disclosure requirements to small business would therefore require the design of appropriate disclosure framework as well as specific accompanying measures.

\section{Engagements climatiques des banques et crédit aux industries intensives en carbone : nouveaux résultats pour la France}

\section{RÉSUMÉ}

Dans cet article, j'examine si et comment les banques alignent leurs déclarations d'engagement pro-climat et leurs actes en termes d'allocation du crédit entre les industries plus ou moins intensives en carbone en France. J'utilise des données désagrégées sur les encours de crédit des principaux groupes bancaires opérant en France vis-à-vis d'une cinquantaine de secteurs industriels et pour deux classes de taille d'emprunteurs, que je fusionne avec des informations sur l'intensité des émissions de gaz à effet de serre de ces secteurs et une note de performance climatique reposant sur une auto-déclaration par les banques pour la période 2010-2017. Mes résultats suggèrent qu'un niveau d'engagement climatique plus élevé déclaré par les banques est effectivement associé à une moindre croissance de leurs prêts aux grandes entreprises dans les cinq secteurs les plus bruns. Toutefois, leurs prêts aux PME dans des secteurs plus ou moins intensifs en carbone n'ont pas été affectés par leurs engagements à verdir leurs activités. Étant donné que les PME ne sont pas tenues de déclarer leurs émissions de carbone, alors que les grandes entreprises le sont, ces résultats donnent à penser qu'un cadre approprié de déclaration des émissions de carbone pour les petites entreprises est susceptible de favoriser la décarbonation des prêts bancaires.

Mots-clés : banques vertes, émissions de gaz à effet de serre, changement climatique.

Les Documents de travail reflètent les idées personnelles de leurs auteurs et n'expriment pas nécessairement la position de la Banque de France. Ce document est disponible sur publications.banque-france.fr 


\section{Introduction.}

Effectively addressing the many challenges raised by the ongoing climate change will require to fund huge amounts of public and private investment over the next two decades. According to recent estimates, some $\$ 6,000$ bns of additional green investment would be needed yearly until 2030 at the global level, while only some $\$ 400$ bns yearly are actually invested so far. ${ }^{1}$. In France alone, which accounts for some $1.6 \%$ of world carbon emissions, additional funding needs would amount to some EUR 60 bns yearly, but half as much were invested in 2015 (Lemmet and Ducret, 2017). Over the last decade, and even more since the Paris Accord of 2015, a number of large banks, including major French groups, have publicly acknowledged they have a role to play in addressing this problem. As a consequence, many banking groups have committed to greening their business and signed international statements or even boasted their planned exit out of some carbon-intensive industries.

Are these statements by large banks mere greenwashing or is bank credit really being reallocated out of brown firms and brown industries? Considering conflicting recent reports by environmental ONGs, the jury still stands out. ${ }^{2}$ In France, for instance, there is no obvious correlation across industries between greenhouse gas (GHG) emission intensity in 2010 and bank credit growth over the period 2010-2017, as Figure 1 shows.

In this paper, I investigate whether banks decrease relatively more their loans to the most carbon-intensive (or "brownest") domestic sectors whenever they claim to be greener. For this purpose, I merge information on industries' greenhouse gas (GHG) emission intensities, climate performance ratings of major banking groups that reflect their self-reported climate commitments, and last but not least, the universe of almost all bilateral bank-firm credit exposures in France over 2010-2017. This rich credit dataset allows me to sort bank credit exposures to each industry according to the size of borrowing firms, in order to separately analyze what drives lending to large corporations vs lending to small firms (SMEs). I find robust evidence in support of a more active reallocation of credit out of fossil-based sectors when banks self-report as more committed to climate change mitigation and adaptation, as higher climate performance scores are associated with less lending to large firms in the five most emission-intensive sectors.

\footnotetext{
${ }^{1}$ Estimates of needed funding as published by the 2016 report of the new Climate Economy. Estimates of actual global funding directed towards fighting against climate change in 2016 as published by the Climate policy initiative.

${ }^{2}$ For instance, the 2017 report of Rainforest witnesses in 2016 a $22 \%$ cut in funding to very damaging fossilenergy projects (shale gas extraction, deep offshore drilling, coal mining etc.) by 37 global banks. Meanwhile, a recent report by Oxfam in December 2018 blames major French banks for their increased funding of the coal extraction and coal plants ever since the Paris Agreement
} 
However, there is no sign of any rebalancing of more committed banks' credit across brown vs green industries when it comes to SME lending. This lack of interest in the carbon intensity of retail lending may contribute to explaining while, in additional tests, I cannot find any conclusive evidence of an effect of domestic banks' climate commitments on industry-level GHG emission growth in France over this period of time.

Figure 1: Emission intensities in 2010 and subsequent credit growth, sector level.

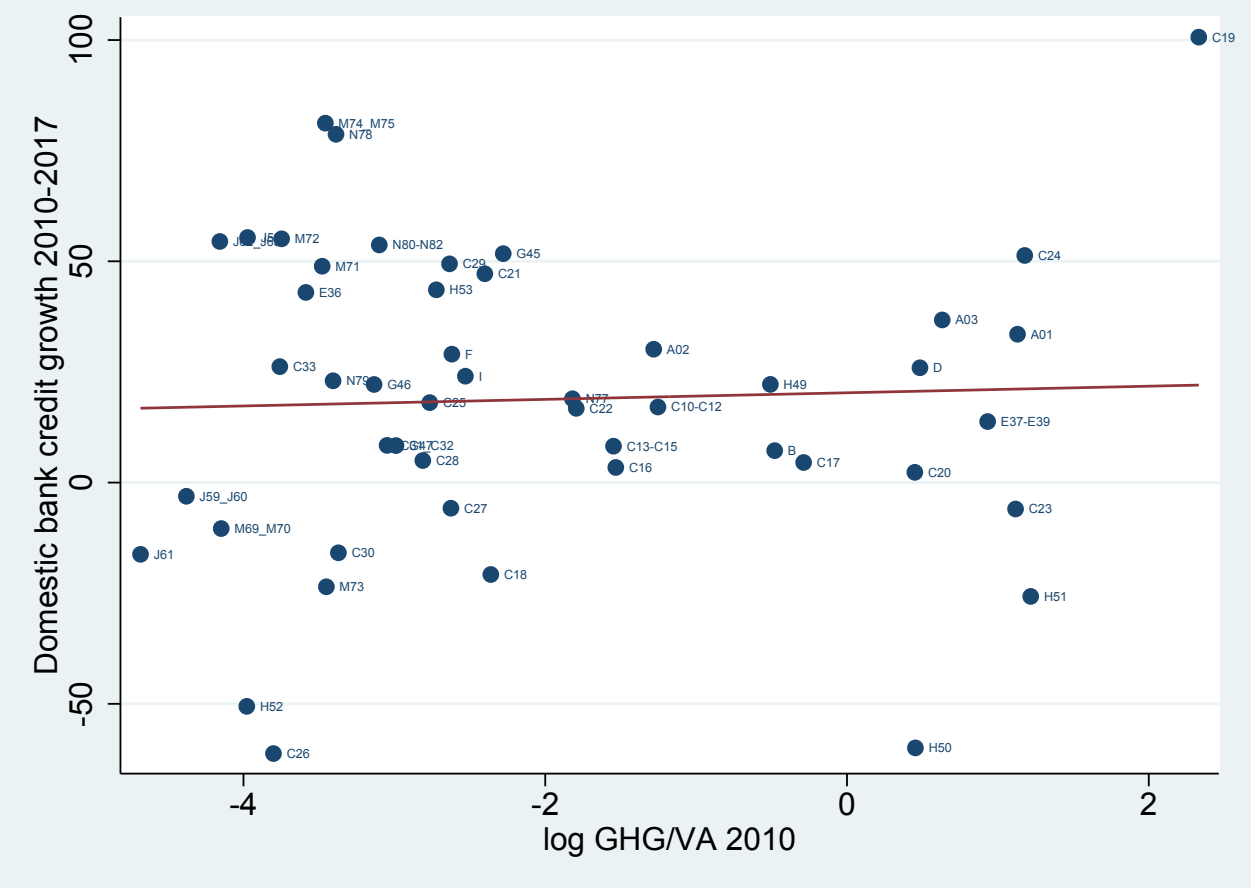

Over the recent years, climate-related concerns in the public have increasingly found their way into more ambitious calls for regulatory policies aimed at mitigating climate change. At the global level, the UN Environment Program-Finance Initiative (UNEP FI) has for instance launched in 2015 the Statement by Financial Institutions on Energy Efficiency which summoned up banks to promote energy efficiency. ${ }^{3}$ Besides, in 2017, the Task force on climaterelated financial disclosure (TCFD) of the G-20's Financial Stability Board published a set of guidelines aiming at increasing banks' transparency on climate-related governance, riskmanagement and reporting. In parallel, several initiatives have been undertaken at the regional or national levels. In Europe, the European Commission has endorsed in March 2018 the

\footnotetext{
${ }^{3}$ UNEP-FI is a partnership between UNEP and the global financial sector created in the wake of the 1992 Earth Summit with a mission to promote sustainable finance. This UNEP-FI Statement was also sponsored by the European Bank for Reconstruction and Development (EBRD).
} 
recommendations of its High-level expert group on sustainable finance. ${ }^{4}$ In France, the 2015 TECV Law has called for the progressive implementation of climate-related stress tests by bank supervisors and increased the scope of climate-related reporting to institutional investors. Last but not least, supervisors have stepped up the pressure they put on banks for them to effectively include climate-related risks in their risk monitoring frameworks and report accordingly. ${ }^{5}$

A number of international banking groups, among which some of the major French banks, have signed up to these and other similar initiatives. The UNEP-FI Statement has for instance received the support of more than 120 banks from more than 40 countries, including 8 French credit institutions. Support for the TCFD has grown to more than 700 companies in 2019, among which 3 French banks and the major French asset management companies (affiliated to banking groups). As a follow-up to the 2015 Paris Agreement, several major French banks have also published commitments to exit (partially or completely) out of funding very carbonintensive industries, like coal mining and coal-based energy production. However, a recent report by the French supervisor (Aubert et al., 2019) suggests that French banks still align their lending policies to climate-related objectives at a slow and unequal pace. ${ }^{6}$

One possible reason for a sluggish adjustment of banks' risk management and loan portfolios to low-carbon objectives may relate to partial or lacking information on the carbon emissions of the borrowers, and more generally the climate impact of the financed economic activities. In this paper, I notably take a closer look at bank lending dynamics to small vs large corporations in France. Distinguishing borrowing firms by size is indeed vindicated since these two types of non-financial firms do not face, at least in this country, the same legal requirements in terms of climate-related reporting. Whereas large and mid-sized corporations with more than 500 employees must report since 2010 on their GHG emissions, smaller firms are exempted from this legal requirement and may only report on a voluntary basis. ${ }^{7}$ However, the

\footnotetext{
${ }^{4}$ Following to the report of the HLEG, the EU's action plan notably encompasses setting up a taxonomy of sustainable activities, a label for green assets and even twisting bank capital requirements in favor of greener investments.

${ }^{5} \mathrm{Cf}$. for instance the recent reports by the European Systemic Risk Board(Gros et al., 2016), as well as the initiatives taken by the Network for greening the financial system (NGFS). The NGFS, a coalition of central banks and bank supervisors launched at the end of 2017 by the Banque de France and 7 other monetary institutes and supervisory authorities, counted some 40 members as of mid-2019. For more information about their workplan, see NGFS (2019).

${ }^{6}$ The French supervisory authority (ACPR) has since 2016 monitored the implementation by banks and insurers of the legal provisions of the 2015 law. Aubert et al. (2019) documented a still large heterogeneity across major French banks regarding their climate-related governance and risk-management strategies. While some banks have largely integrated the analysis of their exposure to climate-related risks into their general risk management framework, several others still seem to disregard these risks and at best communicate about the carbon footprint of their business as part of their general responsible investment policy.

${ }^{7}$ A 2010 law (Grenelle 2 Act, article 75) requires that large firms file every three years a report on their GHG
} 
some 3,8 millions of French small firms account for some $40 \%$ of value added and for $49 \%$ of employment in the non-farm, non-financial sectors. ${ }^{8}$ Although their GHG emissions are difficult to track, recent estimates suggest that small firms also account for some 12 to $14 \%$ of French GHG emissions (Bonduelle and Goujon, 2018). ${ }^{9}$ Meanwhile, SMEs receive a sizable share of bank credit in France, around 40\%. This suggests alone that good lending practices regarding SMEs may significantly contribute to reducing the carbon impact of bank lending in France. However, the lack of appropriate information is likely to either reduce banks' incentives to reallocate their loans out of brown SMEs because this decision is less easily observed by external investors or other stakeholders, or simply hamper such reallocation if banks allocate credit according to firm-level and not sector-level climate-related performance. ${ }^{10}$

To investigate this issue, I exploit a rich dataset that merges information on bank credit broken down by industrial sector and firm size, industries' greenhouse gas emissions, and a measure of banks' climate-related commitments in France since 2010. I get the credit data up to 2017 from the French credit register, which collects quasi-exhaustive information about bilateral bank-firm credit exposures for all chartered banks located in France. The credit register also includes important details about individual borrowers including their (NACE rev2) industry and size. Measures of the (domestically produced) greenhouse gas emissions of French industries at the NACE rev2 2-digit level are compiled by Eurostat from national sources. This data was available up to 2016 at the time of this writing. I scale sectors' annual GHG emissions in kilograms by their value added in euros and use the obtained emission intensities to rank some 50 non-financial, mostly private, sectors from the most to the least polluting ones. Last, I measure banks' greening statements by using CDP's climate-related performance scores, as provided by Bloomberg. CDP is a UK-based non-for-profit organization that rates the ESG policies of listed corporations around the world based on their answers to a detailed proprietary questionnaire. Their ratings are widely used by financial analysts and researchers interested in

emissions (called "Bilan GES réglementaire"). This reporting is however limited to scope 1 and 2 emissions. Since a 2015 law (TECV Act, article 173), non-compliance with this provision entails a 1,500 EUR penalty. The same law has also strengthened the carbon-disclosure requirements of listed corporations and of larger corporations (with a turnover above 100 million EUR). As part of their mandatory ESG reporting, these firms must also report on their scope $3 \mathrm{GHG}$ emissions.

${ }^{8}$ Note that $96 \%$ of these SMEs are very small firms with less than 10 employees. All data refers to 2015.

${ }^{9}$ Including emissions by small trucks, offices and shops (so-called scope 2 emissions), as well as emissions associated with the daily transportation of employees and material production inputs (both part of the so-called scope 3 emissions).

${ }^{10}$ Indeed, the above mentioned recent reports by ONGs like Oxfam (2018) or the Rainforest Alliance Network (2019) are in themselves a proof that credit flows to very brown large companies can be easily tracked and showed of to increase public pressure on incriminated banks. 
indicators of firms' non-financial performance. CDP climate scores are available for five major banking groups operating in France. These five banks account for almost two thirds of total domestic bank lending to non-financial French corporations. About a tenth of their loans to domestic incorporated firms were directed towards the five most emission-intensive sectors in 2017.

I then run panel regressions on this dataset to test whether the growth rate of lending to firms in more GHG emission-intensive (or "browner") industries is relatively slower for banks which post higher climate-related performance scores ("greener banks"). Controlling for industry-, time- and bank-fixed effects, I find that banks' higher CDP ratings are indeed associated with less lending to the five most polluting industries, which made up alone the half of GHG emissions. This reallocation is however entirely explained by banks' lending to large corporations, while no effect is found when looking at the growth rate of credit to SMEs across banks and industries. This result is quite robust to alternative, more stringent, sets of fixed effects, as well as the exclusion of agriculture or oil production and refining. However, "greener" banks do not seem to care much for reducing their business with quite polluting industries outside of the top 5. Last, I turn to additional panel regressions at the sector level to test whether this reallocation of credit out of the brownest sectors contributes to curbing GHG emissions. Although I find some evidence suggesting that top polluting sectors would decrease more their emissions when they are more dependent on greener banks, the significance of the effect is wiped out by the inclusion of year dummies, which also reflects the small size of the sample. It is therefore difficult to draw conclusions.

Some caveats must be raised for a proper understanding of this exercise. A first important caveat is that all these results relate to estimated correlations and should not be interpreted as reflecting causal relations. Indeed, the fact that self-reported greener banks would lend relatively less to large corporations in the brownest industries is here no proof that this reallocation is the consequence of the banks' ex ante commitments. This result could also indeed also consistent with an opposite view that banks would like to depict themselves as green today because they anticipate tougher regulations tomorrow (leading for instance to energy plant closures) and therefore already plan to reduce their exposure to the affected polluting industries. As a matter of fact, tranches in eight coal power plants have been closed since 2010 by the two main operators (EDF and E.ON France) because of expected stricter regulations. ${ }^{11}$ Also, as regards the production of coke and oil refining products $(\mathrm{C} 19$, by far the most carbon-intensive sector

\footnotetext{
${ }^{11}$ Only four coal power generating plants were still active in France as of end 2018. Their closure before 2022 was announced in November 2018.
} 
in 2010), the observed cut in GHG emission intensity by some $20 \%$ between 2010 and 2016 mostly reflects the closure of four refineries over the years 2010-2013, leaving only 9 refineries in activity, including one which was about to be closed as of March 2018 (CITEPA, 2018).

A second limitation faced by the analysis relates to the coarse granularity of the 2-digit industrial sectors, which is however the most disaggregated level at which sector-specific statistics on greenhouse gas emissions are publicly available. For instance, the H49 sector covers all forms of land transportation, from railway to trucks, although different transportation means obviously have a very different impact on global warming. Similarly, the electricity production sector (D) includes both nuclear plants and coal burning thermal plants. ${ }^{12}$

Third, it is important to keep in mind that my metrics of industry-specific bank funding is here limited to bank loans (and credit lines) granted to corporations which are located in France. It is therefore impossible to infer from the results whether large corporates in brown industries really received less total funding in France (i.e., including purchases of bonds and equity) from self-reported greener banks in France, nor whether these banks also reduced their supply of funding to brown industries outside of France. ${ }^{13}$ As the financing of large European companies shifted towards bond issuance instead of bank loans over recent years, one may be concerned that this trend could have affected differently browner industries. ${ }^{14}$ Such trend is however controlled for by the industry-specific fixed effects that I include in the baseline regression. ${ }^{15}$.

In spite of these caveats, two important policy implications can be drawn from this study. First, the link I highlight between sector-level carbon intensity, banks' greening and bank lending to large firms suggests that the available industry-level information on GHG emissions is relevant for banks, or at least is a good proxy of the information that is used by banks. This may be a concern as regulators would prefer to incentivize banks to direct credit to the "greenest" corporations within brown industries, i.e. the firms that invest heavily in greening their dirty

\footnotetext{
${ }^{12}$ The high share of nuclear plants in total electricity production in France (about 75\%) explains why this sector only ranks eighth in terms of emission intensity.

${ }^{13}$ Interestingly, the commitments that some large French banks took at the time of the Paris Accord to exit funding of coal power plants or new coal mines focused on new projects in developed economies, i.e. countries where such business was already on the decline. Fortunately, these banking groups have enlarged the scope of their commitment to exit coal financing since then.

${ }^{14}$ Notably, Battiston and Monasterolo (2019) and Matikainen et al. (2017) point to the high share of brown industries in the corporate bond purchases undertaken by the Eurosystem as part of the CSPP program. Since ECB bond purchases on the secondary market are bound to respecting a rule of "market neutrality", this high share in purchases also reflects the ex ante high share of these industries in the outstanding amounts.

${ }^{15}$ Furthermore, the main result on credit flows to large firms still holds when I control for industry-time fixed effects, although it is statistically less significant
} 
production process, rather than pushing banks to cut funding to an industry altogether.

Second, the results provide support to recent calls for an extension of mandatory carbon disclosure to SMEs (Bonduelle and Goujon, 2018). However, most SMEs are by themselves not in capacity to comply with new rules imposing a detailed reporting on carbon emissions. To avoid important mis- or under-reporting, the implementation of such an extension of disclosure requirements to small business would therefore require the design of appropriate disclosure framework as well as specific accompanying measures.

The remainder of this paper is organized as follows. Section 2 surveys the relevant literature. Section 3 presents the sources of the data. Section 4 presents the empirical model used for the analysis, shows the results and comments on their robustness and economic significance. Last, section 5 concludes.

\section{Literature survey}

This paper contributes to the existing literature by highlighting the link between banks' statements on their climate-related policies and the volume of their actual lending to brown vs green industries. This is also the first study on banks and climate-related risks that covers bank loans to small firms and highlights the potential effects in this respect of a lack of information on the carbon-emissions of SMEs.

In contrast, previous studies have mostly looked at the price effects of corporate environmental responsibility and, partly reflecting data limitations, have focused on listed companies or large firms which are active borrowers in the syndicated loan market. For instance, Goss and Roberts (2011) looked at the impact of firms' corporate social responsibility (CSR) events on the cost of bank loans, while others investigated the impact of firms' CSR (or CER, for Environmental) disclosure on stock prices (cf. e.g., Crifo et al., 2015; Krueger, 2015). ${ }^{16}$ More recently, Zerbib (2019) also looked at the spreads of green bonds to evaluate investors' interest in non-financial, climate-related performance.

Closer to this study, Kleimeier and Viehs (2018) show that firms which voluntarily disclose their carbon emissions enjoy more favorable spreads in the market for syndicated loans and Boermans and Galema (2019) find that Dutch pension funds that actively divest out of carbonintensive stocks do not exhibit impaired financial performance. ${ }^{17}$ Gibson and Krueger (2017)

\footnotetext{
${ }^{16}$ For an extensive survey of the large economic literature on Corporate Environmental Responsibility and its effects, see Crifo and Sinclair-Desgagné (2014).

${ }^{17}$ For a longer run view on on fossil fuel divestment and portfolio performance, see also Trinks et al. (2018).
} 
look at the stock portfolios of investment funds monitored by the US SEC and find that funds' risk-adjusted returns are positively related to their environmental footprint. This link is more pronounced for institutions with longer investment horizons.

A few recent contributions also investigate whether investors, and among them, banks care for the risk of stranded assets in carbon-intensive industries. Notably, Griffin et al. (2015) document a limited reaction of stock returns to scientific news in the years 2012-2013 about the extent of nonburnable fossil fuel reserves. Delis et al. (2018) find that, unless at least 2015, syndicated loans spreads offered by international banks did not reflect any concern for stranded assets of firms heavily invested in fossil fuel reserves. More generally, Krueger et al. (2018) conduct a survey among institutional investors (a fifth of them working in banks) and report that the long-term, larger and ESG-oriented investors consider risk management to be the appropriate way to address climate risks, rather than divestment.

Last, Nitsche and Schrder (2015) investigate whether socially responsible investment (SRI) funds actually invest in line with their claimed ESG objectives and find that they indeed post higher non-financial performance indicators than standard funds. To our knowledge, this paper is however the first to try and formally test the consistency of environmental words and deeds of commercial banks.

\section{Data}

To conduct this analysis, I merge three main sources of information: bank-firm credit data, which I then collapse at the bank-industry level or at the finer level of bank, industry and size of borrowing firms; information on industries' polluting intensity; and last but not least, information on banking groups' green commitments. I detail below these three data sources and explain how I clean the raw datasets for the purpose of the empirical analysis. I then show some descriptive statistics.

Bank-industry credit exposures: I measure credit growth at the bank-industry level using disaggregated information on bilateral bank-firm credit exposures in France over 2006-2017 from the French credit register, which is managed by the Banque de France. The French credit register (Centrale des Risques) collects quasi-exhaustive information on all bilateral exposures of credit institutions chartered in France vis-á-vis all non-financial private and public entities, the vast majority of them being non-financial firms (incorporated companies or individual entrepreneurs). The bilateral reporting threshold is quite low: $25 \mathrm{kEUR}$ for the total bank-firm exposure, including possible off-balance sheet guarantees provided by the bank to the firm. The 
reporting frequency is monthly but I consider here only end-of-year credit exposures since the two other datasets have an annual frequency. I prepare this dataset in several steps. I first drop individual entrepreneurs because of a statistical break due to a change in the reporting guidelines occurring in March 2012, as well as entities which are not corporations (municipalities, unions etc.). I therefore focus exclusively on borrowers which are non-financial corporations. For each firm, defined at the level of the legal unit, detailed information on its industry (at the 5-digit level) as well as on the size class it belongs to is available in the credit register. Size classes are defined according to the 2008 Economy Modernization Act (Loi de modernisation de l'économie, LME). ${ }^{18}$ We use this information to identify credit to SMEs, defined as firms with less than 250 staff and less than 50 million euros of annual sales or less than 43 million euros of total assets. Firms with characteristics above these thresholds are considered large in our setup.

Second and as detailed below, banks' green ratings are available at the banking group level for a handful of major players only. I therefore collapse bank credit exposures at the level of banking groups using proprietary information of the French supervisory authority (ACPR) on bank capital ownership (so-called Groupes économiques d'appartenance, which map individual credit institutions into the banking groups they are affiliated with). In what follows, I generally denote banking groups as "banks" for simplicity.

Third, at the bank-firm level, I define the bilateral credit exposure as the sum of outstanding bank loans and undrawn credit lines. I then collapse this information at the bank-industry level, where industries are defined at the 2-digit level of the NACE rev2 classification. Alternatively, I also consider the size of the borrowing firms in each industry and collapse the credit data at the finer level of bank-industry-size of firms. I can then look at the growth rate of credit granted by each banking group to either larger firms or SMEs in each industry. These growth rates of credit are the dependent variables in my regressions. The presence of some obvious outlier values for bank-industry growth rates, notably reflecting very small total credit exposures for some bank-industry pairs, require some preliminary cleaning and I therefore drop the extreme percentiles of credit growth (below p2 and above p98) in each sample. In spite of this cleaning, the variability of the observed growth rates remains large, allowing absolute annual increases of up to $+164 \%$ in terms of natural growth rates (+97\% in log rates) for corporate credit growth.

GHG emissions: I get sectoral information on greenhouse gas (GHG) emissions since 2008 from Eurostat, and information on sectoral value added from the French statistical institute

\footnotetext{
${ }^{18}$ The LME size is defined by INSEE at the level of a so-called enterprise, which means the smallest set of individual legal units which form an autonomous entity from an economic perspective.
} 
(INSEE). GHG emissions are measured in metric tons and emission intensities are defined as GHG emissions by unit of produced value added (in kg/EUR). ${ }^{19}$ GHG emissions include all emissions of all greenhouse gases, the emitted quantities of various pollutants being converted into $\mathrm{CO} 2$ equivalent using standard heating coefficients. I consider all 2-digit industries in the mostly private, non-financial sectors (NACE-rev2 A to N, except sector K, therefore excluding some low emitting sectors in areas like teaching, human health and services to households -from one-digit sector $\mathrm{P}$ to sector $\mathrm{U})$. Due to some groupings in the original dataset, this leaves me with 49 industrial sectors covering all manufacturing industries, most of services, and including farming, mining and construction activities.

Table A1 in the appendix details the total GHG emissions and emission intensities for the 48 industrial sectors under review. Unsurprisingly, the most polluting sector is the manufacture of coke and refined petroleum products (C19), followed by air transport, with emission intensities of respectively 10.2 and $3.4 \mathrm{~kg} / \mathrm{EUR}$ in 2010 (but only 5.8 and 2.9 in 2015, respectively). The least emitting industries among the A-N non-financial sectors come out to be motion picture, video, television programme production (J59-J60) and telecommunications (J61), with emission intensities in 2020 of $0.01 \mathrm{~kg} / \mathrm{EUR}$.

Banks' climate commitments: following for instance Kleimeier and Viehs (2018), I measure the climate commitments of major French banking groups using ratings computed and shared by the UK-based non-for-profit organization CDP (formerly known as Carbon Disclosure Project) for large listed companies in some 90 countries, including financials. ${ }^{20}$ This rating, dubbed the "CDP climate performance score", is meant to "reflect the level of a company's commitment to climate change mitigation, adaptation, and transparency". CDP sends a questionnaire to listed companies (including financials) and awards points for companies that highlight they are undertaking, or have undertaken, "positive" climate change actions. Scores are calculated only for companies with enough data disclosure for CDP to make an assessment. Importantly, CDP does not check the materiality of reported actions and it takes into account only information from a company's response to the annual climate change questionnaire. The resulting rating does then by construction only reflect companies self-reported commitments to greening their business.

CDP provides climate scores for 5 major listed banking groups operating in France: BNP

\footnotetext{
${ }^{19}$ Eurostat also provides measures of sectoral value added and emission intensities, but the value added series at the date of download ended in 2015 while GHG emissions were available up to 2016. Since VA numbers proved to be very close across the two sources, I recomputed emission intensities using INSEE value added series over 2008-2015.

${ }^{20}$ For more information on CDP, please see at: https://www.cdp.net/en/info/about-us
} 
Paribas (BNPP), Crédit Agricole (CASA), HSBC France, Natixis/BPCE, Société Générale (SG). I use a version of the CDP scores that is disseminated by Bloomberg. Bloomberg converts CDP Climate Performance scores to numerical values from 5 - for Band $A / A^{-}$- down to 1 - for Band $E$. Note that CDP's methodology changed somewhat in 2015, new Bloomberg notes ranging from 1 to 8 . I then rescale the new scores into the old ones using correspondence tables between underlying ratings (from A to E) and notes, as provided by Bloomberg. Figure 2 shows the obtained climate scores for the banking groups included in this study. The scores range between two and five, with a marked dispersion across banks and some important variation through time.

Figure 2: CDP ratings of 5 French major banking groups (2010-2016)

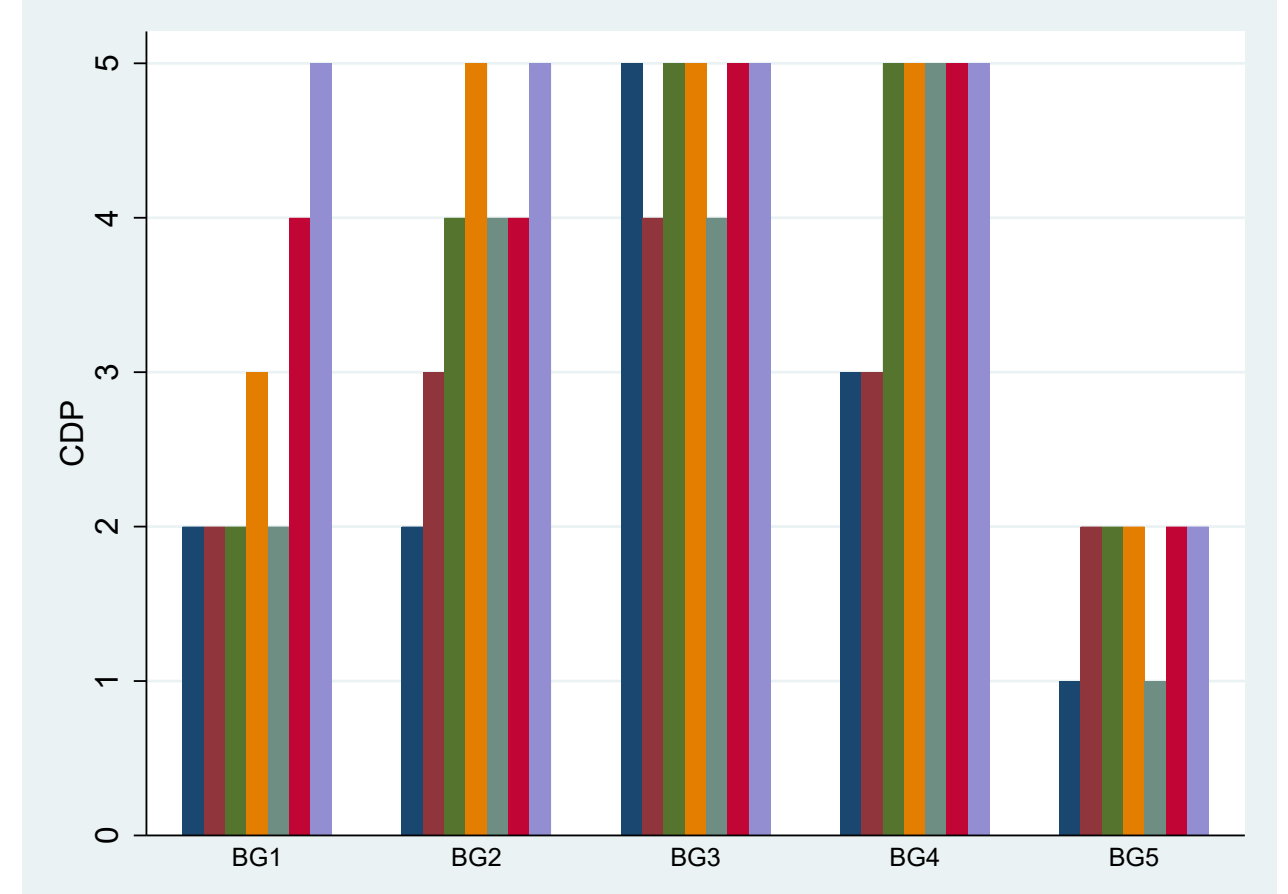

Note. Rescaled CDP ratings rank from 1 (low green commitment) to 5 (high green commitment). Post-2015 ratings adjusted to match the pre-2015 scale. For each banking group (B1 to B5), successive bars correspond to successive years from 2010 to 2016. Source: Carbon Disclosure Project/Bloomberg.

I merge these three datasets using unique banking group identifiers (so-called GEA codes) and 2-digit industry codes. The resulting sample provides detailed information on industryspecific GHG emissions and the sectoral credit exposure, broken down by firm-size, of the 5 major banking groups analyzed by CDP over the period from 2010 to 2017. These 5 banking groups account for two thirds of bank credit to non-financial firms of sectors $\mathrm{A}$ to $\mathrm{N}$ in France. 
Table 1 shows descriptive statistics for the sample used in the regressions. The sample includes above 1,600 bank-industry-specific observations for rates of credit growth, a few dozen less when I look at more granular data on credit to large corporates vs retail credit to SMEs. The average rate of credit growth is at $1.6 \%$ per year. Credit growth is on average lower for small borrowers (at 1.3\%) than for large firms (at 2.1\%). Furthermore, Figure A4 in the Appendix plots emission intensities against the share of SMEs in bank loans to each sector in 2010. The figure confirms that the share of retail lending is not systematically correlated to GHG emission intensities at the industry level, which allows me to conduct the analysis separately for corporate and retail credit supply. However, two highly emitting sectors stand out as being dominated either by large corporations (cokefaction and oil refining) or small companies (farming). Therefore, I exclude these sectors sequentially when checking for the robustness of the baseline results.

Table 1: Bank-sector-level dataset: descriptive statistics.

\begin{tabular}{|c|c|c|c|c|c|c|c|c|}
\hline & \multicolumn{8}{|c|}{ (1) } \\
\hline & Nb.Obs. & Mean & Std.Dev. & Min & p25 & Median & p75 & Max \\
\hline Credit growth (log, pp) & 1637 & 1.587 & 15.282 & -54.08 & -5.48 & 1.11 & 7.87 & 56.07 \\
\hline Credit growth, SMEs (log, pp) & 1583 & 1.324 & 12.812 & -39.80 & -5.59 & 0.68 & 7.27 & 49.32 \\
\hline Credit growth, large firms (log, pp) & 1601 & 2.127 & 23.375 & -84.52 & -8.63 & 0.57 & 11.72 & 97.25 \\
\hline Top 5 EI & 1637 & 0.096 & 0.295 & 0.00 & 0.00 & 0.00 & 0.00 & 1.00 \\
\hline Top 6-10 EI & 1637 & 0.100 & 0.300 & 0.00 & 0.00 & 0.00 & 0.00 & 1.00 \\
\hline $\mathrm{CDP}(-1)$ & 1637 & 3.481 & 1.385 & 1.00 & 2.00 & 4.00 & 5.00 & 5.00 \\
\hline $\log \mathrm{EI}(-1)$ & 1637 & -2.189 & 1.792 & -4.68 & -3.55 & -2.72 & -0.76 & 2.33 \\
\hline Ptf Share (-1) & 1637 & 2.123 & 4.222 & 0.00 & 0.31 & 0.66 & 1.81 & 40.83 \\
\hline CDP*log EI (-1) & 1637 & -7.668 & 7.379 & -23.41 & -13.45 & -7.49 & -2.56 & 9.03 \\
\hline Observations & 1637 & & & & & & & \\
\hline
\end{tabular}

Note. Growth rates and ratios are expressed in percentage points. CDP stands for the CDP climate score of banks, scaled from 1 (low) to 5 (high). $\log E I$ is the GHG emission intensity of industries, measured in kilograms of GHG emissions per EUR of valued added and expressed in logs. Ptf share is the share of industry $s$ in the loan portfolio of banking group $b$.

\section{Results}

In this section, I first show some preliminary univariate results at a semi-aggregate level, then I present the empirical model used for the econometric analysis and present the results of the multivariate regressions. Last, I provide some test of the robustness of these findings and discuss their economic significance. 


\subsection{Preliminary analysis}

In order to get a preliminary visual intuition of the effect of banks' climate commitments on their credit allocation across industries, I first aggregate the dataset along two lines. On the one hand, I group banks according to their average CDP climate score over 2010-2016, thereby contrasting the three banks with the highest average CDP scores and three other banks, two with lower average CDP scores and one without any score. ${ }^{21}$ On the other hand, I contrast the 5 most polluting sectors (as measured with their GHG emission intensities) with all others. These 5 sectors account alone in 2010 for some $50 \%$ of all GHG emissions by firms of mostly private, non-financial sectors in France but of about only $5 \%$ of value added. ${ }^{22}$ I then compute the shares of the top 5 polluting sectors in the credit portfolio of each grouping of banks.

The top panel of Figure 3 shows the results in the spirit of a difference-in-difference exercise. From 2013 on, the share of credit to highly polluting industries declines for the group of more "climate-committed" banks, while it keeps increasing for the group of banks with low CDP scores or no scores. As shown in the intermediate panel of Figure 3, this contrast is much more pronounced when looking at corporate credit only: the share of credit to top polluting industries drops down by some $25 \%$ since 2010 for banks with high CDP scores, while it goes up by some $30 \%$ for less committed banks. ${ }^{23}$ Interestingly however, the pattern is reversed if one focuses on retail credit to SMEs (bottom panel): then the share of credit to small firms in GHG emission-intensive industries goes up for both groupings of banks, whatever their self-reported degree of green commitment. Moreover, the surge is even larger (by some 25\%) for allegedly "greener" banks than for the other three (by some 10\%). However, it is fair to stress that the average share of the 5 most polluting sectors in the SME loan portfolios of the three low-CDPrating banks is about ten times larger than for the three high-CDP-rating banks. This notably reflects the fact that the former banks are on average more invested into domestic agriculture, a sector dominated by SMEs.

It is also interesting to plot the shares of the top 6-10 carbon-intensive industries across bank

\footnotetext{
${ }^{21}$ Statistical confidentiality requirements impose that no information using the credit register is disclosed or displayed for any grouping of less than three banks. I therefore add for the sake of this preliminary exercise credit data for a sixth major French banking group, which does not answer to CDP's questionnaire, so that each of the two grouping includes a minimum of three banks. Together, these six banking groups account for over $80 \%$ of credit to non-financial firms in France.

${ }^{22}$ The top 5 GHG-intensive sectors are the usual culprits: [C19] Manufacture of coke and refined petroleum products, [H51] Air transport, [C24] Manufacture of basic metals, [A01] Farming, [C23] Manufacture of other non-metallic mineral products (which includes cement and glass).

${ }^{23}$ I show in the online Appendix the same series when scaled to their initial level (i.e., $\left.2010=100\right)$ for an easier reading of percentage changes.
} 
Figure 3: Lending shares to top 5 emission-intensive industries: High CDP-rating banks vs others

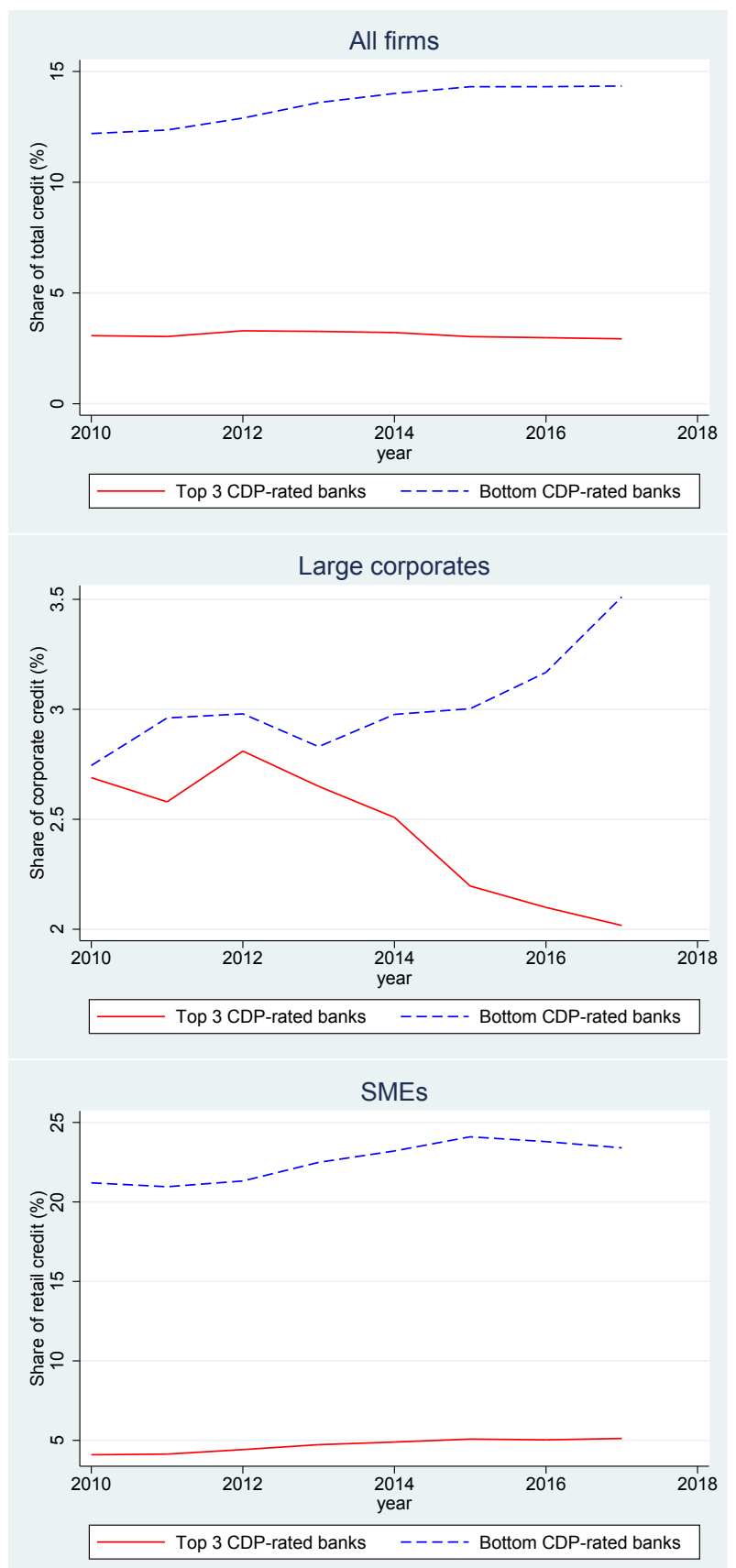

Note. Top CDP-rated banks aggregate the three banking groups with the highest average CDP climate scores over 2010-2016. Bottom CDP-rated banks aggregate the two other banking groups in the main sample and a third major banking group with no CDP rating. Top 5 GHG-intensive sectors are: [C19] Manufacture of coke and refined petroleum products, [H51] Air transport, [C24] Manufacture of basic metals, [A01] Farming, [C23] Manufacture of other non-metallic mineral products. 
Figure 4: Lending shares to top 6-10 emission-intensive industries, corporate vs retail lending: High CDP-rating banks vs others
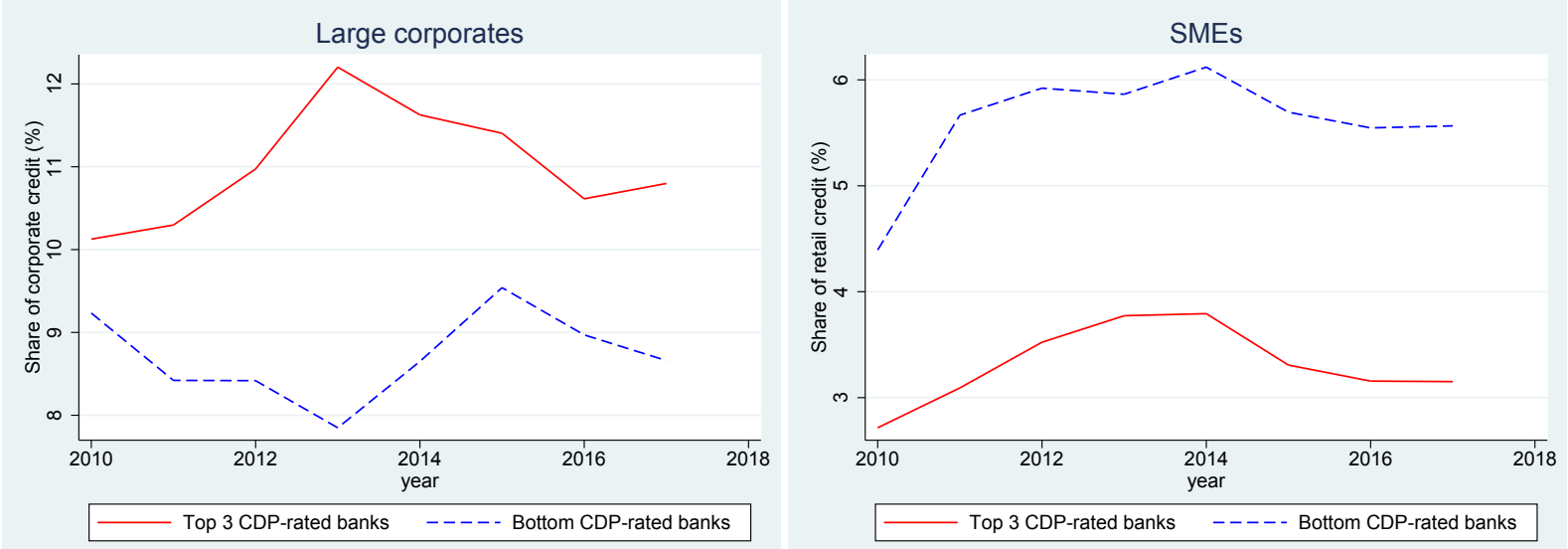

Note. Note: Top CDP-rated banks aggregate the three banking groups with the highest average CDP climate scores over 2010-2016. Bottom CDP-rated banks aggregate the two other banking groups in the main sample and a third major banking group with no CDP rating. Top 6-10 GHG-intensive sectors are: [E37-E39] Sewerage, waste management, remediation activities, [A03] Fishing and aquaculture, [D] Electricity, gas, steam and air conditioning supply, [H50] Water transport, [C20] Manufacture of chemicals and chemical products.

types and borrower sizes. ${ }^{24}$ These five sectors accounted in 2010 for $27 \%$ of GHG emissions and some $5 \%$ of the value added in non-financial, mostly private sectors. Figure 4 shows that the supposedly "greener" banks relatively increased their lending to large firms in these sectors up to 2013, then decreased their relative exposure (cf. left panel). The pattern is inverted as regards the "less green" banks up to 2015, although the average share of their lending to these polluting sectors is lower throughout. After 2015, the shares of the top 6-10 most emissionintensive sectors decreases for both types of banks. As far as SME loans are concerned, the patterns are similar across banks : the share of the top 6-10 carbon-intensive sectors increases up to 2014 and decreases slightly afterward (right panel).

However suggestive, this preliminary visual evidence is potentially biased by a series of factors that cannot be controlled for in such a simple univariate approach. Besides, the potential effects of changes in the CDP scores of the banks are ignored. For these reasons, we turn in the following sections to a more formal econometric analysis.

\footnotetext{
${ }^{24}$ The top 6-10 emission-intensive sectors are the following 5 sectors: [E37-E39] Sewerage, waste management, remediation activities, [A03] Fishing and aquaculture, [D] Electricity, gas, steam and air conditioning supply, [H50] Water transport, and [C20] Manufacture of chemicals and chemical products.
} 


\subsection{Empirical model}

The econometric analysis of the impact of banks' climate commitments on their credit allocation relies on the following empirical model:

$$
\begin{aligned}
\operatorname{CREDITGR}_{b, s, f, t} & =\beta E I_{s, t-1} \cdot C D P_{b, t-1}+\theta C D P_{b, t-1}+\alpha E I_{s, t-1} \\
& +\kappa S H A R E_{b, s, t-1} \\
& +\delta_{s}+\delta_{b}+\delta_{t}
\end{aligned}
$$

where $C R E D I T G R_{b, s, f, t}$ stands for the log credit growth (in percentage points) from banking group $b$ to firms in industry $s$ in year $t$. Subscript $f$ stands here for the size of borrowing firms: I consider alternatively credit to all firms in each industry, then credit to large companies (or "corporate" credit for brevity) or credit to SMEs ("retail" credit) only. $E I_{s, t}$ denotes sector-level GHG-output factor (log of emission intensity in EUR/kg) and $C D P_{b, t}$ denotes the bank-level CDP score (from 1 to 5).

Alternatively, I consider a slightly different specification which allows for a non-linear reaction of banks to industries' emission intensities. Instead of the log value of a sector's emission intensity, I then interact the bank's CDP climate score with two dummy variables for (i) the top 5 and (ii) the top 6-10 carbon-intensive sectors as of 2010, denoted $D^{T o p 5 E I}$ and $D^{\text {Top6-10EI }}$ respectively. Under this non-linear specification, the empirical model reads:

$$
\begin{aligned}
\operatorname{CREDITGR}_{b, s, f, t} & =\beta_{1} D_{s, t-1}^{T o p 5 E I} \cdot C D P_{b, t-1}+\beta_{2} D_{s, t-1}^{T o p 6-10 E I} \cdot C D P_{b, t-1} \\
& +\theta C D P_{b, t-1}+\kappa S H A R E_{b, s, t-1} \\
& +\delta_{s}+\delta_{b}+\delta_{t}
\end{aligned}
$$

In both specifications, the coefficients of interest are the $\beta$ ones, the coefficients of the interacted terms. If banks indeed align words and deeds, we expect $\beta, \beta_{1}$ and $\beta_{2}$ to be negative: credit growth from $b$ to $s$ should be slower whenever the bank self-reports a higher degree of climate commitments (high CDP score) and the sector is known to be more emission-intensive (high EI). I of course include in the regression each of the interacted terms separately, and also the variable $S H A R E_{b, s, t}$, which measures the share of sector $s$ in domestic lending of $b$ (to non-financial firms). Including this variable allows for capturing some possible return-tothe-mean behavior by banks, which presumably monitor their sectoral credit exposures against 
pre-specified targets and therefore would tend to adjust their credit supply downward when their exposure to a specific industry is already very large. Accordingly, I expect coefficient $\kappa$ to be also negative. All explanatory variables are lagged by one year in order to alleviate endogeneity concerns.

In the baseline regressions, I also include sector- and bank-specific fixed effects to control for possible trends in bank credit growth at either the industry or the bank level. This for instance will capture possible expansionary trend of some bank in the market or some trend switch between bank and market financing for some industries over this period of time. Additional year fixed effects also control for all possible macroeconomic shocks that may affect credit supply and demand.

In alternative regressions, I include more demanding sets of fixed effects: bank-year fixed effects, that control for all possible bank-specific supply shocks, and industry-year fixed effects, that control for specific credit demand shocks at the sectoral level. Last, I also test that the results are qualitatively robust when I saturate the model with both time-bank or time-sector and bank-sector fixed effects, which account for possible trends at the bank-sector level. This last set of fixed effects however takes out a large number of degrees of freedom, which comes at the cost of a lower precision of the estimates.

\subsection{Regression results}

Table 2 presents the results of the baseline regressions, assuming a linear specification for industries' carbon-intensities. In columns (1-3), the dependent variable is the bilateral bankindustry growth rate of credit to all firms in each industry, whatever their size. The coefficient of the interaction between the bank's CDP score and the sector's GHG emission intensity, $\beta$, is negative as expected but not significant, whatever the set of fixed effects included as controls. Columns (4-6) show the results of similar regressions when the dependent variable is the growth rate of corporate credit granted by each bank to large firms in each industry. The main coefficient of interest is still negative and not significant, but larger as before. Last, columns (7-9) show the results when the dependent variable is the bilateral bank-industry rate of growth of credit to small firms in each sector. Interestingly, the estimate of the $\beta$ coefficient is now positive, although not significant.

This first set of regressions assumes that banks would react linearly to higher (log) levels of emission intensities when setting their lending targets to each industry in line with their public green statements. It is however more realistic to assume that more climate-committed banks may concentrate their adjustment on the most polluting sectors, as effective cuts to high GHG 
Table 2: Green banks and credit growth to browner sectors: by borrower size.

\begin{tabular}{lccccccccc}
\hline \hline & & All & & \multicolumn{3}{c}{ Large firms } & \multicolumn{4}{c}{ SMEs } \\
& $(1)$ & $(2)$ & $(3)$ & $(4)$ & $(5)$ & $(6)$ & $(7)$ & $(8)$ & $(9)$ \\
\hline CDP*log EI (-1) & -0.201 & -0.202 & -0.105 & -0.366 & -0.368 & -0.139 & 0.158 & 0.160 & 0.189 \\
& {$[0.144]$} & {$[0.144]$} & {$[0.182]$} & {$[0.226]$} & {$[0.228]$} & {$[0.274]$} & {$[0.140]$} & {$[0.142]$} & {$[0.156]$} \\
CDP (-1) & 0.350 & & & 1.070 & & & 0.701 & & \\
& {$[0.763]$} & & & {$[1.269]$} & & & {$[0.680]$} & & \\
log EI (-1) & 5.880 & 5.806 & & 0.944 & 0.957 & & $8.048^{*}$ & 8.075 \\
& {$[4.667]$} & {$[4.559]$} & & {$[6.588]$} & {$[6.494]$} & & {$[4.812]$} & {$[4.900]$} & \\
Ptf Share (-1) & $-0.297^{* *}$ & $-0.296^{* *}$ & -0.151 & $-0.315^{* *}$ & $-0.315^{* *}$ & -0.119 & -0.106 & -0.108 & 0.015 \\
& {$[0.123]$} & {$[0.122]$} & {$[0.092]$} & {$[0.151]$} & {$[0.151]$} & {$[0.131]$} & {$[0.092]$} & {$[0.091]$} & {$[0.096]$} \\
\hline Sector FE & Yes & Yes & No & Yes & Yes & No & Yes & Yes & No \\
Time FE & Yes & No & No & Yes & No & No & Yes & No & No \\
Bank FE & Yes & No & No & Yes & No & No & Yes & No & No \\
Sec.-Time FE & No & No & Yes & No & No & Yes & No & No & Yes \\
Bank-Time FE & No & Yes & Yes & No & Yes & Yes & No & Yes & Yes \\
Observations & 1637 & 1637 & 1636 & 1621 & 1621 & 1620 & 1635 & 1635 & 1634 \\
R-Squared & 0.06 & 0.08 & 0.33 & 0.05 & 0.07 & 0.33 & 0.11 & 0.16 & 0.39 \\
\hline \hline
\end{tabular}

Note. OLS regressions. Dependent variable: $(\log )$ growth rate of credit at the bank-sector level to firms in different size classes as specified in columns. Sample period: 2011-2017. Clustered standard errors (sector*bank) in parentheses unless otherwise stated.

emitters are more likely to reduce rapidly the carbon footprint and climate risk exposure of the bank, while they are also easier to communicate to both the public and investors.

Table 3 shows therefore the results of similar regressions but under the non-linear specification detailed above. The bank's CDP climate score is now interacted with two dummy variables for the top 5 and the top 6-10 emission intensive sectors as of 2010, respectively. I find some evidence that banks with higher CDP climate scores decrease relatively more their lending to firms in the 5 brownest industries. The estimated $\beta_{1}$ coefficient is now strongly significant when I pool borrowers of all sizes within each industry, but the effect is even stronger when I focus on credit flows to large firms only. In contrast, the climate commitments of banks seem to have no effect on their supply of loans to SMEs in the brownest industries. The coefficient of interest is however smaller and less significant when I include sector-time fixed effects in the set of controls, but this also reflects the relatively small size of the sample. ${ }^{25}$ Last, the estimated $\beta_{2}$ coefficient is non-significantly different from zero whatever the type of firms and the set of controls. This tends to confirm that banks interpret their climate commitments mostly in terms of their credit exposure to a handful of very carbon-intensive sectors.

\footnotetext{
${ }^{25}$ The controls now absorb some 340 degrees of freedom, i.e. more than $20 \%$ of observations.
} 
Table 3: Green banks and credit growth to browner sectors: dummies for top 5 and top 6-10 polluting sectors.

\begin{tabular}{lccccccccc}
\hline \hline & & All & \multicolumn{3}{c}{ Large firms } & \multicolumn{3}{c}{ SMEs } \\
& $(1)$ & $(2)$ & $(3)$ & $(4)$ & $(5)$ & $(6)$ & $(7)$ & $(8)$ & $(9)$ \\
\hline CDP*EI Top 5 (-1) & $-2.327^{* * *}$ & $-2.287^{* * *}$ & $-1.713^{*}$ & $-3.745^{* * *}$ & $-3.702^{* * *}$ & $-2.431^{*}$ & 1.273 & 1.315 & 1.275 \\
& {$[0.845]$} & {$[0.829]$} & {$[1.014]$} & {$[1.244]$} & {$[1.271]$} & {$[1.398]$} & {$[0.863]$} & {$[0.903]$} & {$[0.831]$} \\
CDP*EI Top 6-10 (-1) & 0.484 & 0.454 & 0.465 & 1.815 & 1.821 & 2.325 & -0.882 & -0.820 & -0.370 \\
& {$[0.865]$} & {$[0.896]$} & {$[1.256]$} & {$[1.488]$} & {$[1.506]$} & {$[1.945]$} & {$[0.848]$} & {$[0.839]$} & {$[1.039]$} \\
CDP (-1) & 0.956 & & & $2.066^{*}$ & & & 0.329 & & \\
& {$[0.656]$} & & & {$[1.152]$} & & & {$[0.570]$} & & \\
Ptf Share (-1) & $-0.309^{* *}$ & $-0.308^{* *}$ & $-0.166^{*}$ & $-0.337^{* *}$ & $-0.336^{* *}$ & -0.152 & -0.101 & -0.102 & 0.011 \\
& {$[0.129]$} & {$[0.128]$} & {$[0.097]$} & {$[0.160]$} & {$[0.161]$} & {$[0.136]$} & {$[0.085]$} & {$[0.084]$} & {$[0.084]$} \\
\hline Sector FE & Yes & Yes & No & Yes & Yes & No & Yes & Yes & No \\
Time FE & Yes & No & No & Yes & No & No & Yes & No & No \\
Bank FE & Yes & No & No & Yes & No & No & Yes & No & No \\
Sec.-Time FE & No & No & Yes & No & No & Yes & No & No & Yes \\
Bank-Time FE & No & Yes & Yes & No & Yes & Yes & No & Yes & Yes \\
Observations & 1637 & 1637 & 1636 & 1621 & 1621 & 1620 & 1635 & 1635 & 1634 \\
R-Squared & 0.06 & 0.08 & 0.33 & 0.06 & 0.07 & 0.34 & 0.11 & 0.15 & 0.39 \\
\hline \hline
\end{tabular}

Note. OLS regressions. Dependent variable: (log) growth rate of credit at the bank-sector level to firms in different size classes as specified in columns. Sample period: 2011-2017. Clustered standard errors (sector*bank) in parentheses unless otherwise stated. Top 5 emission intensive sectors are: [C19] Manufacture of coke and refined petroleum products, [H51] Air transport, [C24] Manufacture of basic metals, [A01] Farming, [C23] Manufacture of other non-metallic mineral products. "Top 6-10" emission intensive sectors are the following 5 sectors: [E37E39] Sewerage, waste management, remediation activities, [A03] Fishing and aquaculture, [D] Electricity, gas, steam and air conditioning supply, [H50] Water transport and [C20] Manufacture of chemicals and chemical products.

\subsection{Robustness}

I conduct three additional robustness tests of these results. First, I exclude farming from the sample. Farming is indeed special as most of operating firms are small entities (as reflected by the share of retail in total bank lending to this sector, which comes close to 100\%) and as one major banking group accounts for a large share of credit to this market. Table A2 in the appendix shows the results. They remain roughly unchanged. Interestingly, the positive $\beta_{1}$ coefficient that I obtain in the case of retail lending now becomes weakly significant (at the $10 \%$ level).

Second, I exclude the manufacture of coke and refined oil products, which also belongs to the group of top 5 emission-intensive sectors. As mentioned above, 4 oil refineries out of 13 closed since 2010 in France, which explains a substantial part of the massive reduction in the emission-intensity of this industry (by some $43 \%$ over 6 years). These closures are likely to be accompanied or even preceded with lending cuts by all lenders, but this could affect disproportionately the banks that self-report as green, for instance if they were more able to anticipate the closures. Tables A3 shows the results for a specification including either 
bank-time and sector-time fixed effects or sector-bank fixed effects and, respectively, time or bank-time dummies. The $\beta_{1}$ coefficient becomes somewhat larger and more significant in the most demanding specification for large firms (column 6). It also comes out as positive in the most demanding specification as regards lending to small firms (column 9). While banklevel (supply) and sector-level (demand) shocks are controlled for, self-reported green banks tend to increase more their lending to SMEs in brown industries such as air transport, and manufacturing of metals and other mineral products.

Third, I run the same regressions as above (still using dummies for the 5 and 10 most emitting sectors) but this time I include sector-bank fixed effects as controls (as well as time or time-bank fixed effects). The interacted effect of a greener bank and a browner sector on lending growth is therefore entirely identified in the time (within-) dimension. The results are reported in Table A4 in the appendix. Although this specification sharply reduces the number of degrees of freedom and hence yields more imprecise estimates, the main coefficient of interest still comes out as significantly negative (at the 10 percent level) when one considers lending to large corporations, but remains slightly positive as far as retail lending is concerned. ${ }^{26}$

\subsection{Discussion}

What is the economic significance of the measured effect? To answer this question for the baseline non-linear specification, let us consider the case of bank credit growth to large corporates and compare how banks at the 25th and 75th percentiles of the CDP climate score (i.e., $C D P=2$ vs $C D P=5$ ) would lend to the top 5 emission-intensive sectors vs low-emission sectors (with emission intensities in the bottom 39), all other things equal. Using the estimated coefficient $\beta=-3.7$ and computing the difference of projected growth rates across banks and sectors, it comes out that a self-reported green bank would reduce its relative growth rate of credit to the most polluting sectors by 11.1 percentage points more than would a less committed bank do. This is again economically significant. However, the overall impact of banks' climate commitments on their credit allocation across sectors may be mitigated by banks' lending policy regarding small firms.

What is then the real impact of these adjustments to the credit policy of banks that boast greener commitments? To have a say on this, I run an additional exercise, where I try to explain the growth rate of GHG emissions at the sector level as a function of the CDP climate score

\footnotetext{
${ }^{26}$ An additional table in the appendix also shows the results we get when we both exclude coke and oil refining and include sector-bank fixed effects. They are qualitatively the same as in the previous case.
} 
of the average bank lending to this sector. For this purpose, I first define the CDP score of a sector's lenders as the credit weighted average of the individual CDP scores of banks actually lending to this sector. Second, I compound the effect of lenders' green commitment by a measure of the sectors' dependence to external funding. For the latter, I take a standard RajanZingales (RZ, 1998) index of industries' financial dependence, as updated by Guevara and Maudos (2011). For each industry, the RZ index is computed as the median across listed firms in that industry of the share of capital expenditures which is not funded by the firm's savings. Guevara and Maudos (ibid.) compute measures of the RZ index for 48 manufacturing and services ISIC rev3 sectors in the UK over 1993-2003, which I then map into 37 of the NACE rev2 sectors of my dataset. This measure of financial dependence is by construction arguably exogenous to funding and investment decisions affecting French industries over 2010-2017.

I then run the following regression at the sector level:

$$
\begin{aligned}
G H G G R_{s, t} & =\beta D_{s, t-1}^{T o p E I} \cdot C D P_{s, t-1} \cdot R Z_{s}+\gamma D_{s, t-1}^{T o p E I} \cdot C D P_{s, t-1} \\
& +\theta C D P_{s, t-1}+\kappa C D P_{s, t-1} \cdot R Z_{s} \\
& +\delta_{s}+\delta_{t}
\end{aligned}
$$

where $G H G G R_{s, t}$ denotes the sector-level growth of GHG emissions (in logs), $D_{s, t}^{T o p E I}$ is a dummy that takes the value of one if the sector belongs to the most emission-intensive indus$\operatorname{tries}^{27}, C D P_{s, t}$ is the average CDP climate score of banks lending to sector $s$ (from 1 to 5), $R Z_{s}$ is a sector-level Rajan-Zingales index of financial dependence (UK, 1993-2003) and $V A G R_{s, t}$ stands for the sector-level value added growth. I also include sector and time fixed effects. With this regression, I aim to test whether browner industries that structurally need more external financing and depend on more committed lenders tend to decrease relatively more their GHG emissions. I therefore expect $\beta$ to be negative if this hypothesis holds.

Table 4 presents the results. I control for different sets of fixed effects and include in some specifications the lagged $(\log )$ level of GHG emissions by the industry. The main coefficient of interest, $\beta$, comes out as negative as expected, and is weakly significant unless I also include lagged GHG emissions by the industry and/or time fixed effects in order to absorb all unspecified macroeconomic developments. This suggests that, whatever the apparent twist to

\footnotetext{
${ }^{27}$ I consider here the 6 industries with emission intensities above $1 \mathrm{~kg} /$ EUR and for which a RZ index is available (which excludes agriculture, fishing and waste management): (C19) Manufacture of coke and refined petroleum products, (H51) Air transport, (C24) Manufacture of basic metals, (C23) Manufacture of other non-metallic mineral products, (E37-E39) Sewerage, waste management, remediation activities, (A03) Fishing and aquaculture, (D) Electricity, gas, steam and air conditioning supply, (C20) Manufacture of chemicals and chemical products.
} 
the corporate lending activity of self-reported greener banks, this move may not be enough to actually contribute to curbing the emissions of the most polluting industries.

\section{Conclusion}

In this paper, I investigate whether banks that report to be more committed to tackling climate change do adjust their lending policy accordingly and tend to shun more borrowers from carbon-intensive industries. I measure the climate commitment of five major French banking groups using CDP's climate performance index and industries' carbon-intensity using greenhouse gas emissions per unit of value added for some 50 industries. This study is also the first to shed light on possible differences in banks' greening policies regarding their supply of credit to large corporations vs to small firms in each industry. Over the period of 2010 to 2017, I find robust evidence that higher levels of self-reported climate commitments are associated with a lower growth of lending to large corporations in the five brownest industries, which alone account for about a half of domestic GHG emissions French of the private, non-financial businesses. However, banks' climate commitments do not seem to affect their lending to other very emitting sectors beyond the top 5 ones. Last but not least, banks do not seem to care for the carbon-intensity of SMEs they lend to, whatever their degree of alleged climate responsibility. Overall, these findings suggest that banks align green words to deeds, but only to some extent. "Greener" banks' apparent lack of concern about SMEs carbon-intensity suggests that lacking information may matter here. As SMEs arguably account for a substantial share of aggregate value added and GHG emissions in France, my results come in support to recent calls for extending appropriate carbon-reporting requirements to SMEs.

This study is a first step towards a better assessment of whether and how financial institutions' green statements transmit to effective policies in order to alleviate climate change. Further research is however needed to extend the analysis with more comprehensive datasets. Extensions should consider including more banks in the analysis (for instance by directly collecting statements in a survey as Krueger et al. (2018) do), including more instruments beyond loans (notably holdings of debt securities and equity), and, last but not least, use finer measure of emission intensities at the level of corporations instead of industries. This last improvement will remain however out of reach as regards the SMEs as long as no carbon reporting framework for small firms has been devised and implemented. 
Table 4: GHG emissions growth and dependence on funding by greener banks, industry panel.

\begin{tabular}{lccc}
\hline \hline & $(1)$ & $(2)$ & $(3)$ \\
& $2011-16$ & $2011-16$ & $2011-16$ \\
Growth Rate of GHG & $\mathrm{b} / \mathrm{se}$ & $\mathrm{b} / \mathrm{se}$ & $\mathrm{b} / \mathrm{se}$ \\
\hline Top EI*CDP*RZ (-1) & $-29.563^{* *}$ & -17.021 & -14.935 \\
& {$[14.824]$} & {$[14.974]$} & {$[19.352]$} \\
& & & \\
Top EI*CDP (-1) & $18.332^{* *}$ & 9.842 & 8.204 \\
& {$[7.614]$} & {$[8.194]$} & {$[10.445]$} \\
CDP*RZ (-1) & -5.124 & -5.977 & -5.070 \\
& {$[7.878]$} & {$[6.068]$} & {$[5.016]$} \\
CDP (-1) & 1.524 & 0.183 & 4.575 \\
& {$[3.820]$} & {$[2.834]$} & {$[3.464]$} \\
log GHG (-1) & & & \\
& & $-51.762^{* * *}$ & $-50.233^{* * *}$ \\
Sector FE & Yes & Yes & Yes \\
Time FE & No & No & Yes \\
Observations & 184 & 184 & 184 \\
R2 & 0.16 & 0.50 & 0.59 \\
\hline
\end{tabular}

Note. OLS regressions. Sample period: 2011-2016. White-robust standard errors in parentheses. The "top EI sectors" are those with emission intensities above $1 \mathrm{~kg} / \mathrm{EUR}$ in 2010 for which the RZ index is available: (C19) Manufacture of coke and refined petroleum products, (H51) Air transport, (C24) Manufacture of basic metals, (C23) Manufacture of other non-metallic mineral products, (E37-E39) Sewerage, waste management, remediation activities, (A03) Fishing and aquaculture, (D) Electricity, gas, steam and air conditioning supply, (C20) Manufacture of chemicals and chemical products. 


\section{References}

Aubert, Marion, William Bach, Sébastien Diot, and Lucas Vernet, 2019, Les groupes bancaires francais face au risque climatique, Analyses et Synthèses 101, ACPR.

Battiston, Stefano and Irene Monasterolo, 2019, How could the ECBs monetary policy support the sustainable finance transition?, mimeo, University of Zurich.

Boermans, Martijn A. and Rients Galema, 2019, Are pension funds actively decarbonizing their portfolios?, Ecological Economics 161, 50 -60.

Bonduelle, Antoine and Stéphanie Goujon, 2018, TPE-PME, comment réussir le passage a la neutralité carbone?, Avis du CESE 2018/22, Conseil Economique Social et Environnemental.

CITEPA, 2018, Inventaire des missions de polluants atmosphriques en France mtropolitaine, format CEE-NU Mars, Centre Interprofessionnel Technique dEtude de la Pollution Atmosphrique.

Crifo, Patricia and Bernard Sinclair-Desgagné, 2014, The Economics of Corporate Environmental Responsibility, International Review of Environmental and Resource Economics 7.3-4, 279-297.

Crifo, Patricia, Vanina D. Forget, and Sabrina Teyssier, 2015, The price of environmental, social and governance practice disclosure: An experiment with professional private equity investors, Journal of Corporate Finance 30.C, 168-194.

Delis, Manthos, Kathrin de Greiff, and Steven Ongena, 2018, Being Stranded on the Carbon Bubble? Climate Policy Risk and the Pricing of Bank Loans, Swiss Finance Institute Research Paper Series 18-10, Swiss Finance Institute.

Gibson, Rajna and Philipp Krueger, 2017, The Sustainability Footprint of Institutional Investors, Swiss Finance Institute Research Paper Series 17-05, Swiss Finance Institute.

Goss, Allen and Gordon S. Roberts, 2011, The impact of corporate social responsibility on the cost of bank loans, Journal of Banking and Finance 35.7, 1794-1810.

Griffin, Paul A., Amy Myers Jaffe, David H. Lont, and Rosa Dominguez-Faus, 2015, Science and the stock market: Investors' recognition of unburnable carbon, Energy Economics 52, $1-12$.

Gros, Robert, Philip Lane, Sam Langfield, Sini Matikainen, Marco Pagano, Dirk Schoenmaker, and Javier Suarez, 2016, Too late, too sudden: Transition to a low carbon economy and systemic risk, Reports of the Advisory Scientific Committee 6/February, European Systemic Risk Board. 
Guevara, Juan Fernndez de and Joaquin Maudos, 2011, Banking competition and economic growth: cross-country evidence, The European Journal of Finance 17.8, 739-764.

Kleimeier, Stefanie and P. M. Viehs, 2018, Carbon disclosure, emission levels, and the cost of debt, Research Memorandum 003, Maastricht University, Graduate School of Business and Economics (GSBE).

Krueger, Philipp, 2015, Corporate goodness and shareholder wealth, Journal of Financial Economics $115,304-329$.

Krueger, Philipp, Zacharias Sautner, and Laura Starks, 2018, The importance of climate risks for institutional investors, Reasearch Paper Series 2018/58, Swiss Finance Institute.

Lemmet, Sylvie and Pierre Ducret, 2017, Pour une stratégie francaise de la finance verte, Rapport MM. les Ministres Nicolas Hulot et Bruno Le Maire, MTES/MINEFI.

Matikainen, S., E. Campiglio, and D. Zenghelis, 2017, The climate impact of quantitative easing, Policy Paper of the Grantham Research Institute on Climate Change and the Environment, London School of Economics and Political Science.

NGFS, 2019, A call for action: Climate change as a source of financial risk, First report of the Network for Greening the Financial System, Banque de France/NGFS Secretariat.

Nitsche, Christin and Michael Schrder, 2015, Are SRI funds conventional funds in disguise or do they live up to their name?, Frankfurt School - Working Paper Series 217, Frankfurt School of Finance and Management.

Trinks, Arjan, Bert Scholtens, Machiel Mulder, and Lammertjan Dam, 2018, Fossil Fuel Divestment and Portfolio Performance, Ecological Economics 146, 740 -748.

Zerbib, Olivier David, 2019, The effect of pro-environmental preferences on bond prices: Evidence from green bonds, Journal of Banking and Finance 98.C, 39-60. 


\section{Appendix}

Table A1: GHG emissions, emission intensities and value added by industrial sectors

\begin{tabular}{|c|c|c|c|c|c|c|}
\hline Variable Names & EI 2010 & EI 2016 & $\%$ GHG 2010 & $\%$ VA 2010 & $\Delta \ln (G H G)$ & $\Delta \ln (E I)$ \\
\hline C19 Manufacture of coke and refi & 10.29 & 5.81 & 5.39 & 0.18 & -20.55 & -57.28 \\
\hline H51 Air transport & 3.38 & 2.92 & 5.61 & 0.57 & -0.87 & -14.48 \\
\hline C24 Manufacture of basic metals & 3.25 & 3.72 & 5.90 & 0.62 & -8.71 & 13.49 \\
\hline A01 Crop and animal production, & 3.10 & 3.20 & 25.59 & 2.83 & 0.39 & 3.32 \\
\hline C23 Manufacture of other non-met & 3.06 & 2.54 & 6.62 & 0.74 & -16.59 & -18.63 \\
\hline E37-E39 Sewerage, waste manageme & 2.54 & 2.06 & 7.64 & 1.03 & -16.36 & -20.73 \\
\hline A03 Fishing and aquaculture & 1.88 & 1.74 & 0.37 & 0.07 & 2.45 & -7.47 \\
\hline D Electricity, gas, steam and ai & 1.62 & 0.77 & 11.83 & 2.50 & -37.56 & -74.17 \\
\hline H50 Water transport & 1.57 & 1.81 & 1.05 & 0.23 & 4.23 & 13.81 \\
\hline C20 Manufacture of chemicals and & 1.57 & 1.08 & 6.46 & 1.41 & -12.06 & -36.83 \\
\hline C17 Manufacture of paper and pap & 0.75 & 0.66 & 0.83 & 0.38 & 2.45 & -12.37 \\
\hline B Mining and quarrying & 0.62 & 0.53 & 0.40 & 0.22 & -32.76 & -14.65 \\
\hline H49 Land transport and transport & 0.60 & 0.46 & 6.54 & 3.72 & -13.30 & -27.26 \\
\hline C10-C12 Manufacture of food prod & 0.29 & 0.19 & 3.00 & 3.59 & -22.04 & -41.61 \\
\hline A02 Forestry and logging & 0.28 & 0.19 & 0.17 & 0.21 & 0.82 & -39.88 \\
\hline C16 Manufacture of wood and of $p$ & 0.22 & 0.14 & 0.18 & 0.28 & -38.52 & -44.75 \\
\hline C13-C15 Manufacture of textiles, & 0.21 & 0.15 & 0.30 & 0.48 & -28.89 & -35.23 \\
\hline $\mathrm{C} 22$ Manufacture of rubber and $\mathrm{pl}$ & 0.17 & 0.13 & 0.49 & 1.01 & -15.44 & -26.66 \\
\hline N77 Rental and leasing activitie & 0.16 & 0.15 & 1.33 & 2.81 & 4.32 & -6.68 \\
\hline G45 Wholesale and retail trade a & 0.10 & 0.10 & 0.81 & 2.69 & -2.07 & -7.05 \\
\hline C18 Printing and reproduction of & 0.09 & 0.08 & 0.11 & 0.40 & -29.45 & -21.03 \\
\hline C21 Manufacture of basic pharmac & 0.09 & 0.06 & 0.30 & 1.14 & -40.84 & -45.13 \\
\hline I Accommodation and food service & 0.08 & 0.06 & 1.07 & 4.58 & -7.10 & -22.69 \\
\hline F Construction & 0.07 & 0.08 & 2.23 & 10.49 & 5.15 & 4.94 \\
\hline C27 Manufacture of electrical eq & 0.07 & 0.06 & 0.15 & 0.69 & -24.33 & -21.06 \\
\hline C29 Manufacture of motor vehicle & 0.07 & 0.06 & 0.29 & 1.39 & -22.06 & -14.40 \\
\hline H53 Postal and courier activitie & 0.07 & 0.07 & 0.16 & 0.83 & -3.54 & 0.68 \\
\hline C25 Manufacture of fabricated me & 0.06 & 0.05 & 0.34 & 1.83 & -14.34 & -19.26 \\
\hline C28 Manufacture of machinery and & 0.06 & 0.05 & 0.19 & 1.09 & -16.02 & -24.24 \\
\hline G47 Retail trade, except of moto & 0.05 & 0.04 & 1.09 & 7.42 & -5.49 & -16.57 \\
\hline C31 C32 Manufacture of furniture & 0.05 & 0.04 & 0.09 & 0.68 & -19.01 & -25.32 \\
\hline N80-N82 Security and investigati & 0.05 & 0.04 & 0.48 & 3.63 & -2.29 & -18.38 \\
\hline G46 Wholesale trade, except of m & 0.04 & 0.04 & 1.05 & 8.28 & -1.14 & -8.00 \\
\hline C30 Manufacture of other transpo & 0.03 & 0.02 & 0.11 & 1.10 & -28.75 & -64.05 \\
\hline N78 Employment activities & 0.03 & 0.02 & 0.25 & 2.56 & -17.25 & -36.60 \\
\hline N79 Travel agency, tour operator & 0.03 & 0.03 & 0.02 & 0.20 & -14.19 & -22.99 \\
\hline M73 Advertising and market resea & 0.03 & 0.03 & 0.08 & 0.86 & -6.11 & -7.37 \\
\hline M74 M75 Other professional, scie & 0.03 & 0.03 & 0.05 & 0.50 & 8.81 & -19.55 \\
\hline M71 Architectural and engineerin & 0.03 & 0.03 & 0.23 & 2.52 & 3.35 & -14.67 \\
\hline E36 Water collection, treatment & 0.03 & 0.03 & 0.03 & 0.32 & 7.93 & 10.55 \\
\hline M72 Scientific research and deve & 0.02 & 0.02 & 0.20 & 2.89 & -10.99 & -23.35 \\
\hline C33 Repair and installation of $\mathrm{m}$ & 0.02 & 0.02 & 0.13 & 1.85 & -0.66 & -16.10 \\
\hline C26 Manufacture of computer, ele & 0.02 & 0.02 & 0.07 & 1.11 & -6.97 & -9.57 \\
\hline J58 Publishing activities & 0.02 & 0.01 & 0.06 & 1.10 & -8.33 & -24.66 \\
\hline H52 Warehousing and support acti & 0.02 & 0.02 & 0.15 & 2.71 & -8.57 & -14.56 \\
\hline M69 M70 Legal and accounting act & 0.02 & 0.01 & 0.29 & 6.38 & -3.46 & -18.95 \\
\hline
\end{tabular}

Continued on next page.. 
... table A1 continued

\begin{tabular}{lcccccc}
\hline \hline \multicolumn{1}{c}{ Variable Names } & EI 2010 & EI 2016 & \% GHG 2010 & \% VA 2010 & $\Delta \ln (G H G)$ & $\Delta \ln (E I)$ \\
\hline J62 J63 Computer programming, co & 0.02 & 0.01 & 0.18 & 3.96 & -4.89 & -30.98 \\
J59 J60 Motion picture, video, t & 0.01 & 0.01 & 0.04 & 0.97 & -9.95 & -24.82 \\
J61 Telecommunications & 0.01 & 0.01 & 0.08 & 2.93 & 0.46 & 18.10 \\
\hline \hline
\end{tabular}


Table A2: Green banks and credit growth to browner sectors: dummies for top 5 and top 6-10 polluting sectors, excl. farming.

\begin{tabular}{lccccccccc}
\hline \hline & & All & \multicolumn{3}{c}{ Large firms } & \multicolumn{3}{c}{ SMEs } \\
& $(1)$ & $(2)$ & $(3)$ & $(4)$ & $(5)$ & $(6)$ & $(7)$ & $(8)$ & $(9)$ \\
\hline CDP*EI Top 5 (-1) & $-2.391^{* *}$ & $-2.340^{* *}$ & $-2.144^{*}$ & $-3.272^{* *}$ & $-3.202^{* *}$ & $-2.842^{*}$ & $1.821^{*}$ & $1.874^{*}$ & 1.470 \\
& {$[1.024]$} & {$[1.010]$} & {$[1.241]$} & {$[1.427]$} & {$[1.466]$} & {$[1.638]$} & {$[1.032]$} & {$[1.086]$} & {$[1.043]$} \\
CDP*EI Top 6-10 (-1) & 0.490 & 0.461 & 0.465 & 1.825 & 1.830 & 2.315 & -0.881 & -0.819 & -0.370 \\
& {$[0.866]$} & {$[0.897]$} & {$[1.258]$} & {$[1.487]$} & {$[1.507]$} & {$[1.948]$} & {$[0.849]$} & {$[0.839]$} & {$[1.040]$} \\
CDP (-1) & 0.916 & & & $1.995^{*}$ & & & 0.346 & & \\
& {$[0.666]$} & & & {$[1.137]$} & & & {$[0.579]$} & & \\
Ptf Share (-1) & $-0.364^{*}$ & $-0.359^{*}$ & -0.179 & $-0.395^{*}$ & $-0.394^{*}$ & -0.194 & -0.131 & -0.128 & 0.026 \\
& {$[0.194]$} & {$[0.193]$} & {$[0.139]$} & {$[0.233]$} & {$[0.234]$} & {$[0.191]$} & {$[0.126]$} & {$[0.123]$} & {$[0.117]$} \\
\hline Sector FE & Yes & Yes & No & Yes & Yes & No & Yes & Yes & No \\
Time FE & Yes & No & No & Yes & No & No & Yes & No & No \\
Bank FE & Yes & No & No & Yes & No & No & Yes & No & No \\
Sec.-Time FE & No & No & Yes & No & No & Yes & No & No & Yes \\
Bank-Time FE & No & Yes & Yes & No & Yes & Yes & No & Yes & Yes \\
Observations & 1602 & 1602 & 1601 & 1586 & 1586 & 1585 & 1600 & 1600 & 1599 \\
R-Squared & 0.06 & 0.08 & 0.33 & 0.06 & 0.07 & 0.33 & 0.11 & 0.16 & 0.39 \\
\hline \hline
\end{tabular}

Note. OLS regressions. Dependent variable: $(\log )$ growth rate of credit at the bank-sector level to firms in different size classes as specified in columns. Sample period: 2011-2017. Clustered standard errors (sector*bank) in parentheses unless otherwise stated.

Table A3: Green banks and credit growth to browner sectors: dummies for top 5 and top 6-10 polluting sectors, excl. coke and oil refineries.

\begin{tabular}{lccccccccc}
\hline \hline & & All & & \multicolumn{3}{c}{ Large firms } & \multicolumn{3}{c}{ SMEs } \\
& $(1)$ & $(2)$ & $(3)$ & $(4)$ & $(5)$ & $(6)$ & $(7)$ & $(8)$ & $(9)$ \\
\hline CDP*EI Top 5 (-1) & $-2.436^{* * *}$ & $-2.418^{* * *}$ & $-1.980^{*}$ & $-3.622^{* * *}$ & $-3.603^{* * *}$ & $-2.933^{* *}$ & 1.010 & 1.087 & $1.564^{* *}$ \\
& {$[0.618]$} & {$[0.611]$} & {$[1.024]$} & {$[1.087]$} & {$[1.102]$} & {$[1.473]$} & {$[0.879]$} & {$[0.909]$} & {$[0.738]$} \\
CDP*EI Top 6-10 (-1) & 0.480 & 0.443 & 0.456 & 1.816 & 1.827 & 2.330 & -0.883 & -0.821 & -0.372 \\
& {$[0.865]$} & {$[0.889]$} & {$[1.249]$} & {$[1.492]$} & {$[1.508]$} & {$[1.949]$} & {$[0.846]$} & {$[0.832]$} & {$[1.037]$} \\
CDP (-1) & 0.893 & & & 1.826 & & & 0.273 & & \\
& {$[0.653]$} & & & {$[1.153]$} & & & {$[0.574]$} & & \\
Ptf Share (-1) & $-0.310^{* *}$ & $-0.309^{* *}$ & $-0.169^{*}$ & $-0.335^{* *}$ & $-0.334^{* *}$ & -0.159 & -0.107 & -0.107 & 0.015 \\
& {$[0.128]$} & {$[0.128]$} & {$[0.098]$} & {$[0.159]$} & {$[0.160]$} & {$[0.136]$} & {$[0.084]$} & {$[0.083]$} & {$[0.083]$} \\
\hline Sector FE & Yes & Yes & No & Yes & Yes & No & Yes & Yes & No \\
Time FE & Yes & No & No & Yes & No & No & Yes & No & No \\
Bank FE & Yes & No & No & Yes & No & No & Yes & No & No \\
Sec.-Time FE & No & No & Yes & No & No & Yes & No & No & Yes \\
Bank-Time FE & No & Yes & Yes & No & Yes & Yes & No & Yes & Yes \\
Observations & 1615 & 1615 & 1614 & 1597 & 1597 & 1596 & 1609 & 1609 & 1608 \\
R-Squared & 0.06 & 0.08 & 0.33 & 0.06 & 0.07 & 0.34 & 0.11 & 0.17 & 0.40 \\
\hline
\end{tabular}

Note. OLS regressions. Dependent variable: (log) growth rate of credit at the bank-sector level to firms in different size classes as specified in columns. Sample period: 2011-2017. Clustered standard errors (sector*bank) in parentheses unless otherwise stated. 
Table A4: Green banks and credit growth to browner sectors: dummies for top 5 and top 6-10 polluting sectors, including bank-sector fixed effects (within estimates).

\begin{tabular}{|c|c|c|c|c|c|c|c|c|c|}
\hline & \multicolumn{3}{|c|}{ All } & \multicolumn{3}{|c|}{ Large firms } & \multicolumn{3}{|c|}{ SMEs } \\
\hline & (1) & (2) & (3) & (4) & (5) & (6) & (7) & (8) & (9) \\
\hline \multirow[t]{2}{*}{ CDP*EI Top $5(-1)$} & $-1.713^{*}$ & -2.832 & $-4.725^{*}$ & $-2.431^{*}$ & -3.777 & $-6.142^{*}$ & 1.275 & 0.760 & 2.844 \\
\hline & [1.014] & [1.814] & [2.483] & [1.398] & [2.694] & [3.329] & {$[0.831]$} & {$[1.701]$} & {$[2.374]$} \\
\hline \multirow[t]{2}{*}{ CDP*EI Top 6-10 (-1) } & 0.465 & 0.799 & -0.769 & 2.325 & 1.923 & 1.781 & -0.370 & -1.477 & $-2.924^{*}$ \\
\hline & {$[1.256]$} & {$[1.255]$} & {$[1.723]$} & [1.945] & [1.787] & {$[2.448]$} & [1.039] & [1.683] & [1.662] \\
\hline \multirow[t]{2}{*}{$\operatorname{CDP}(-1)$} & & 1.017 & & & $2.077^{*}$ & & & 0.497 & \\
\hline & & {$[0.661]$} & & & [1.132] & & & {$[0.568]$} & \\
\hline \multirow[t]{2}{*}{ Ptf Share (-1) } & $-0.166^{*}$ & $-8.331^{* * *}$ & $-8.560^{* * *}$ & -0.152 & $-10.159^{* * *}$ & $-10.788^{* * *}$ & 0.011 & $-3.109^{* * *}$ & $-2.962^{* * *}$ \\
\hline & {$[0.097]$} & [1.698] & {$[1.855]$} & {$[0.136]$} & [2.274] & [2.449] & {$[0.084]$} & {$[0.890]$} & [1.068] \\
\hline Time FE & No & Yes & No & No & Yes & No & No & Yes & No \\
\hline Sec.-Time FE & Yes & No & No & Yes & No & No & Yes & No & No \\
\hline Bank-Time FE & Yes & No & Yes & Yes & No & Yes & Yes & No & Yes \\
\hline Bank-Sec. FE & No & Yes & Yes & No & Yes & Yes & No & Yes & Yes \\
\hline Observations & 1636 & 1637 & 1401 & 1620 & 1620 & 1386 & 1634 & 1634 & 1401 \\
\hline R-Squared & 0.33 & 0.19 & 0.22 & 0.34 & 0.16 & 0.21 & 0.39 & 0.21 & 0.28 \\
\hline
\end{tabular}

Note. OLS regressions. Dependent variable: $(\log )$ growth rate of credit at the bank-sector level to firms in different size classes as specified in columns. Sample period: 2011-2017. Clustered standard errors (sector*bank) in parentheses unless otherwise stated.

Table A5: Green banks and credit growth to browner sectors: dummies for top 5 and top 6-10 polluting sectors, excl. coke and oil refineries (within estimates).

\begin{tabular}{|c|c|c|c|c|c|c|c|c|c|}
\hline & \multicolumn{3}{|c|}{ All } & \multicolumn{3}{|c|}{ Large firms } & \multicolumn{3}{|c|}{ SMEs } \\
\hline & (1) & (2) & (3) & (4) & (5) & (6) & (7) & (8) & (9) \\
\hline \multirow[t]{2}{*}{ CDP*EI Top $5(-1)$} & $-1.980^{*}$ & -2.773 & $-4.492^{* *}$ & $-2.933^{* *}$ & -3.835 & $-6.450^{*}$ & $1.564^{* *}$ & -0.287 & 0.953 \\
\hline & {$[1.024]$} & [1.686] & {$[1.802]$} & {$[1.473]$} & [3.003] & [3.510] & {$[0.738]$} & [1.843] & {$[2.584]$} \\
\hline \multirow[t]{2}{*}{ CDP*EI Top 6-10 (-1) } & 0.456 & 0.793 & -0.791 & 2.330 & 1.926 & 1.816 & -0.372 & -1.477 & $-2.973^{*}$ \\
\hline & [1.249] & [1.257] & {$[1.710]$} & [1.949] & {$[1.790]$} & {$[2.451]$} & [1.037] & [1.681] & [1.659] \\
\hline \multirow[t]{2}{*}{$\mathrm{CDP}(-1)$} & & 0.951 & & & $1.883^{*}$ & & & 0.483 & \\
\hline & & {$[0.663]$} & & & [1.132] & & & {$[0.570]$} & \\
\hline \multirow[t]{2}{*}{ Ptf Share (-1) } & $-0.169^{*}$ & $-8.311^{* * *}$ & $-8.542^{* * *}$ & -0.159 & $-10.116^{* * *}$ & $-10.721^{* * *}$ & 0.015 & $-3.082^{* * *}$ & $-2.927^{* * *}$ \\
\hline & {$[0.098]$} & [1.696] & [1.847] & {$[0.136]$} & [2.277] & [2.450] & {$[0.083]$} & [0.898] & {$[1.068]$} \\
\hline Time FE & No & Yes & No & No & Yes & No & No & Yes & No \\
\hline Sec.-Time FE & Yes & No & No & Yes & No & No & Yes & No & No \\
\hline Bank-Time FE & Yes & No & Yes & Yes & No & Yes & Yes & No & Yes \\
\hline Bank-Sec. FE & No & Yes & Yes & No & Yes & Yes & No & Yes & Yes \\
\hline Observations & 1614 & 1615 & 1383 & 1596 & 1596 & 1366 & 1608 & 1609 & 1380 \\
\hline R-Squared & 0.33 & 0.18 & 0.22 & 0.34 & 0.16 & 0.21 & 0.40 & 0.22 & 0.29 \\
\hline
\end{tabular}

Note. OLS regressions. Dependent variable: $(\log )$ growth rate of credit at the bank-sector level to firms in different size classes as specified in columns. Sample period: 2011-2017. Clustered standard errors (sector*bank) in parentheses unless otherwise stated. 
Table A6: Sector-level dataset: descriptive statistics.

\begin{tabular}{lcccccccc}
\hline \hline & & \multicolumn{1}{c}{$(1)$} & & & & \\
& & & & & & & \\
& Nb.Obs. & Mean & Std.Dev. & min & p25 & Median & p75 & max \\
\hline GHG growth & 184 & -2.453 & 6.236 & -21.60 & -5.70 & -1.83 & 1.67 & 19.07 \\
RZ index & 184 & 0.436 & 0.123 & 0.16 & 0.35 & 0.42 & 0.52 & 0.72 \\
$\log$ EI (-1) & 184 & -2.136 & 1.826 & -4.68 & -3.55 & -2.65 & -0.64 & 2.33 \\
CDP (-1) & 184 & 2.801 & 0.572 & 1.79 & 2.40 & 2.70 & 3.27 & 4.22 \\
$\log$ EI*CDP (-1) & 184 & -6.010 & 5.545 & -18.57 & -9.59 & -6.77 & -1.90 & 6.92 \\
$\log$ EI*RZ (-1) & 184 & -0.864 & 0.811 & -2.56 & -1.39 & -1.04 & -0.39 & 0.98 \\
CDP*RZ (-1) & 184 & 1.220 & 0.432 & 0.33 & 0.92 & 1.14 & 1.45 & 2.84 \\
$\log$ EI*CDP*RZ (-1) & 184 & -2.423 & 2.433 & -9.90 & -3.96 & -2.58 & -1.06 & 2.90 \\
VA growth & 184 & 1.319 & 11.556 & -113.02 & -1.24 & 1.55 & 3.86 & 80.07 \\
\hline Observations & 184 & & & & & & & \\
\hline \hline
\end{tabular}


Figure A1: Share of credit to SMEs in total credit to non-financial corporations (selected A-N sectors)

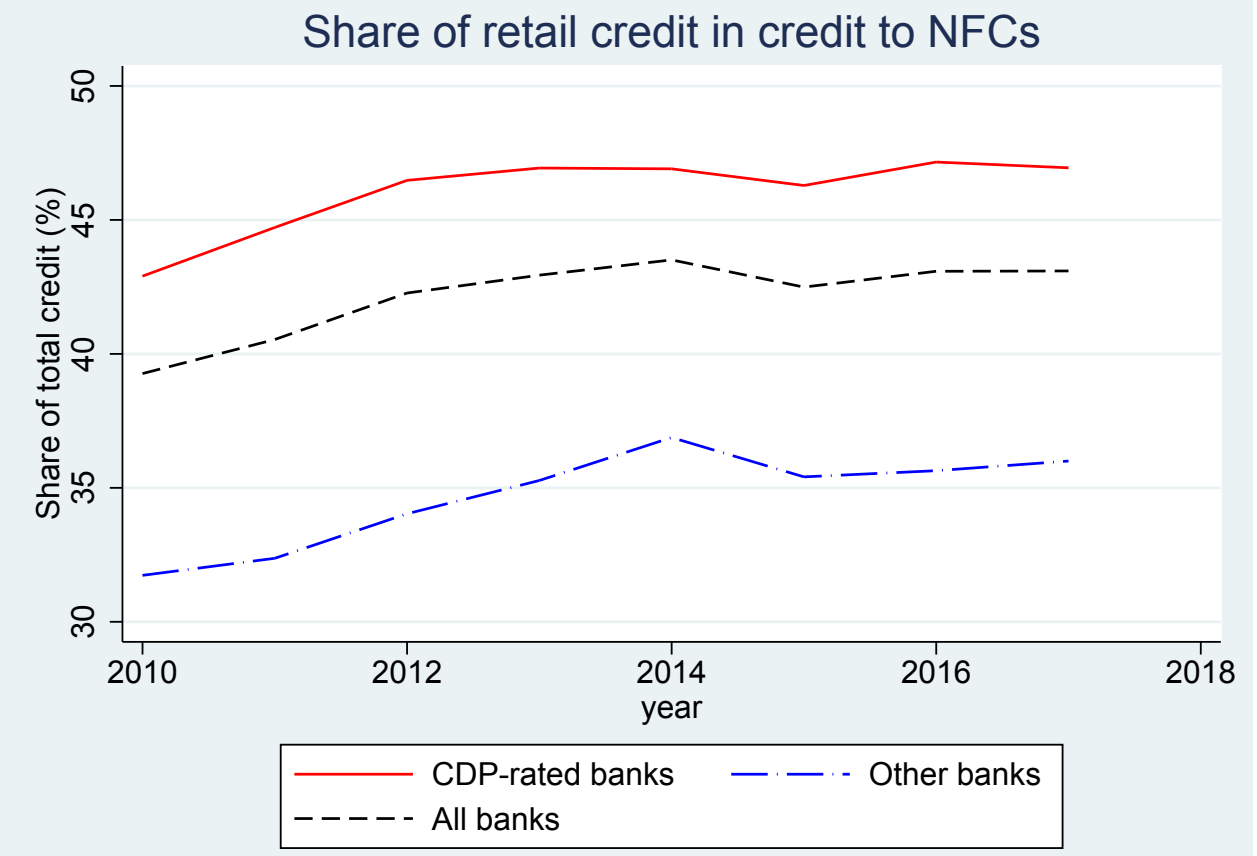


Figure A2: Lending shares to top 5 emission-intensive industries: High CDP-rating banks vs others (rescaled: $2010=100$ )
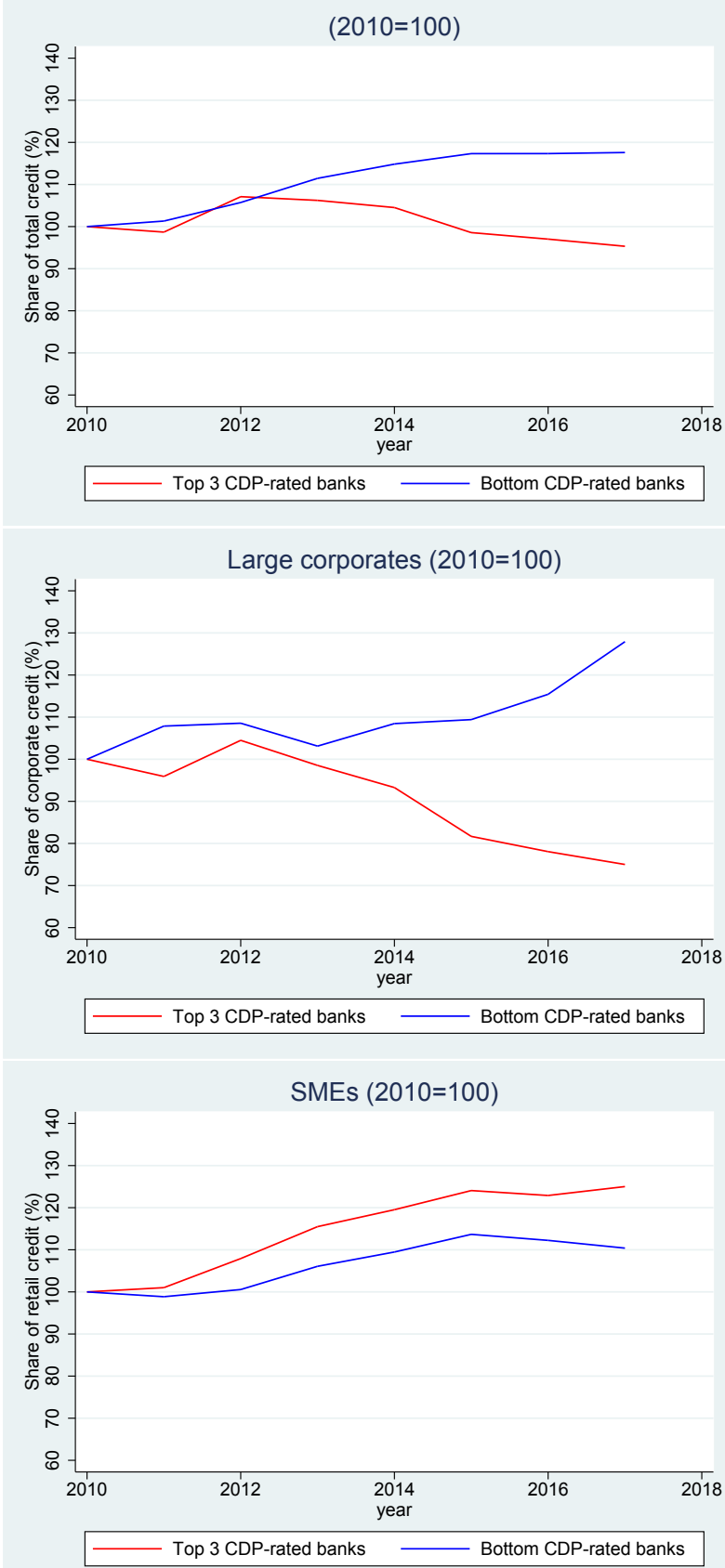

Note. Top CDP-rated banks aggregate the three banking groups with the highest average CDP climate scores over 2010-2016. Bottom CDP-rated banks aggregate the two other banking groups in the main sample and a third major banking group with no CDP rating. Top 5 GHG-intensive sectors are: [C19] Manufacture of coke and refined petroleum products, [H51] Air transport, [C24] Manufacture of basic metals, [A01] Farming, [C23] Manufacture of other non-metallic mineral products. These 5 sectors: 50\% of GHG, 5\% of VA in 2010 (in A-N sectors). 
Figure A3: GHG emissions and emission intensities in 2010, sector level.

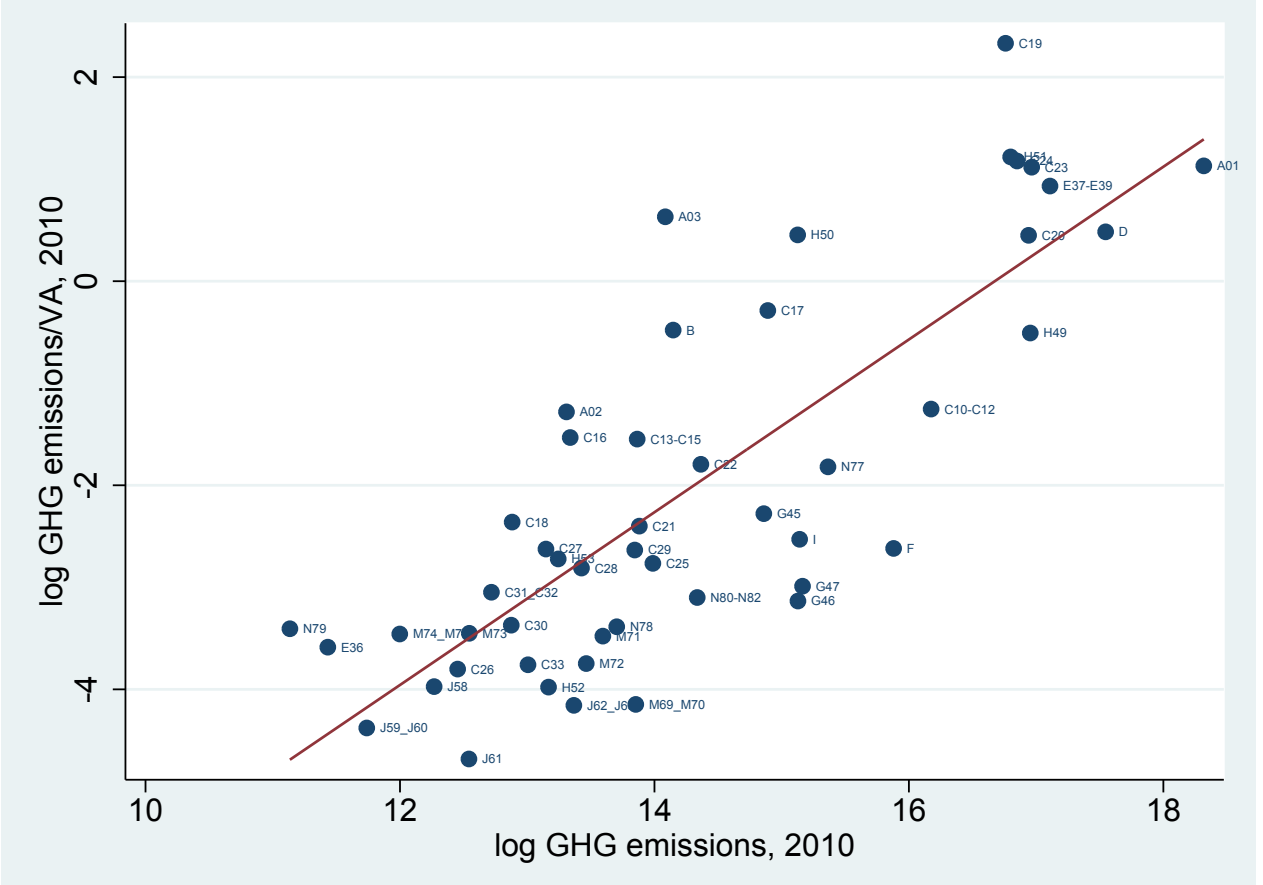

Figure A4: GHG emission intensities and share of bank credit to SMEs, sector level.

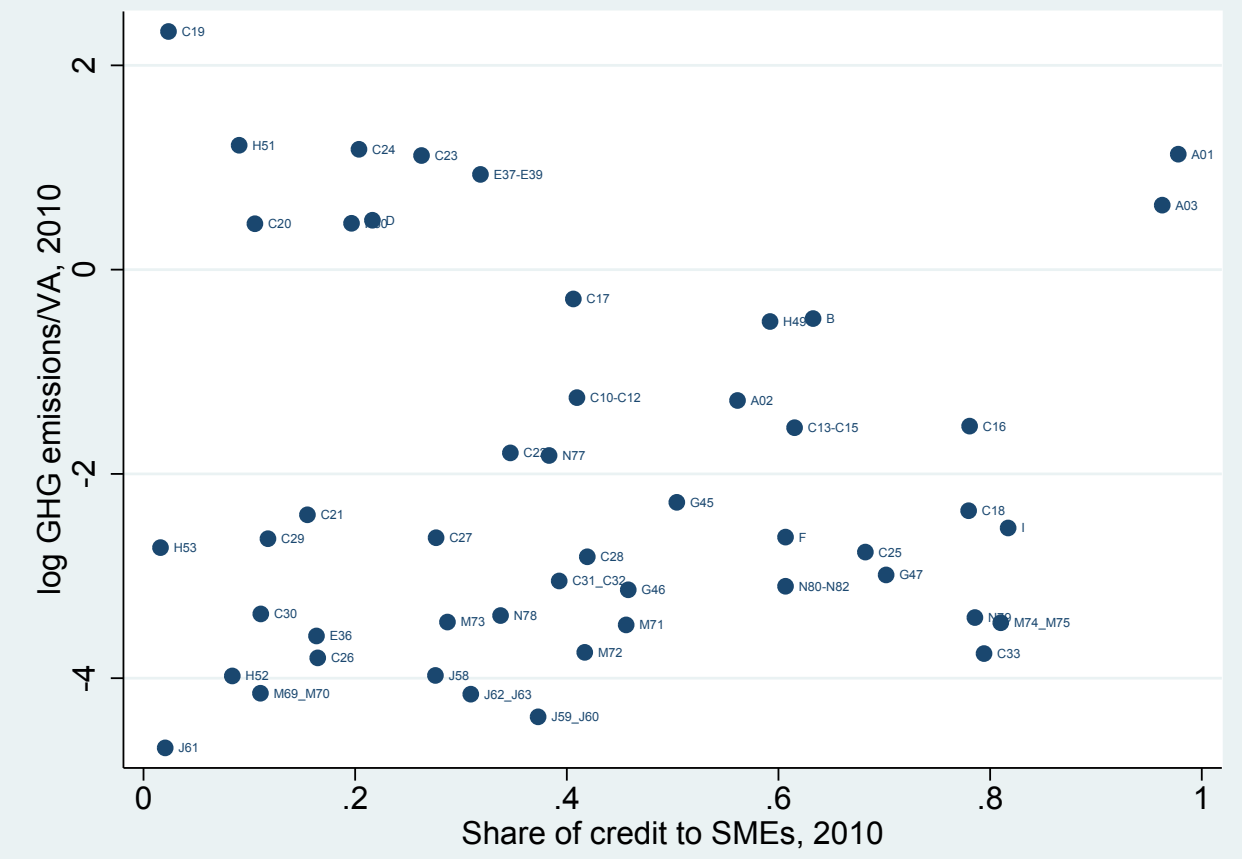

